\title{
Hard, Soft, and Embedded: Implementing Principles on Promoting Responsible Sovereign Lending and Borrowing
}

Anna Gelpern

Georgetown University Law Center, ag1348@law.georgetown.edu

This paper can be downloaded free of charge from:

https://scholarship.law.georgetown.edu/facpub/1860

https://ssrn.com/abstract=2041027

This open-access article is brought to you by the Georgetown Law Library. Posted with permission of the author. Follow this and additional works at: https://scholarship.law.georgetown.edu/facpub

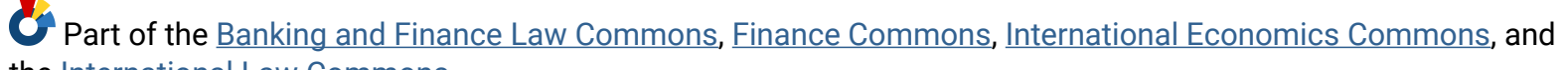
the International Law Commons 


\section{HARD, SOFT, AND EMBEDDED: \\ IMPLementing Principles on Promoting \\ RESPONSIBLE SOVEREIGN LENDING AND BORROWING}

By Anna Gelpern

American University Washington College of Law

and Georgetown University Law Center

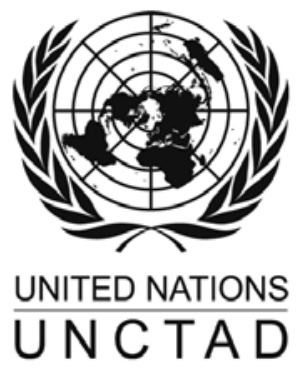

April 2012 Version 


\section{Table of Contents}

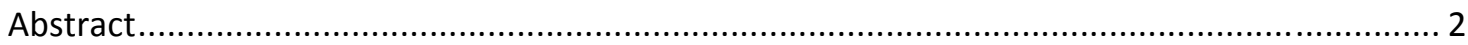

Acknowledgements.............................................................................................. 2

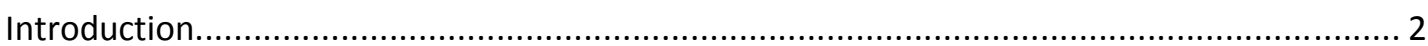

Part I: Hard Law, Soft Law, and New Governance in Sovereign Debt................................ 8

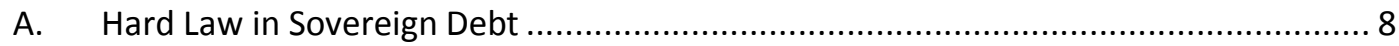

B. Soft Law in Sovereign Debt and International Financial Regulation...................... 12

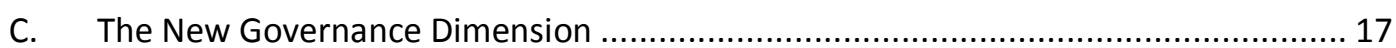

Part II: Ancestors and Analogues .................................................................... 22

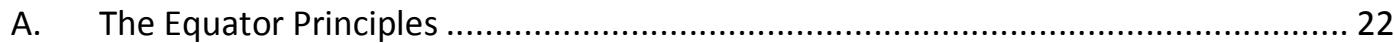

B. Extractive Industries Transparency Initiative .......................................... 25

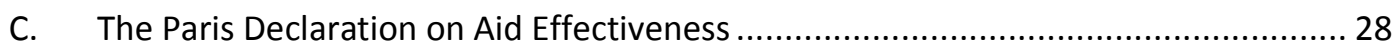

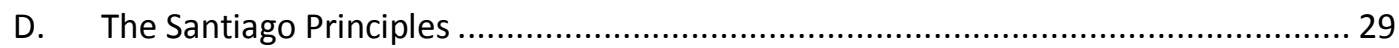

E. Principles for Stable Capital Flows and Fair Debt Restructuring .......................... 32

Part III: An "All of the Above" Implementation Strategy ............................................ 36

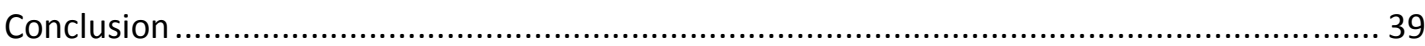




\begin{abstract}
This paper, prepared for UNCTAD's initiative on responsible sovereign lending and borrowing, considers concrete strategies for implementing the Principles. It draws on studies in soft law and new governance, and on the recent experience in promoting best practices in international finance, including project finance, extraction revenue management, foreign aid, sovereign investment, and sovereign borrowing in the capital markets. It recommends maintaining the current non-binding character of the Principles, while embedding implementation in multi-stakeholder arrangements for ongoing disclosure, assessment, interpretation, and adaptation. This strategy has the best chance of changing behavior in sovereign lending and borrowing by creating constituencies for implementation and sustained compliance.
\end{abstract}

\title{
Acknowledgements
}

I am grateful to Juan Pablo Bohoslavsky, Chris Brummer, Barry Carter, Esther Cho, Ryan Farha, Amanda Giglio, Mitu Gulati, Heather Hughes, Breanna Peterson, Mabel Shaw, Jodi Short, Andy Stamm, and Brian Stewart for their help with this paper. The views and conclusions reflected in this paper are solely those of the author and are in no way intended to reflect the views of UNCTAD or any of the institutions with which the author is affiliated.

\section{Introduction}

Sovereign debt exists in a sparse legal space. Debt contract enforcement is uncertain. ${ }^{1}$ There are no formal bankruptcy procedures to guide debt adjustment in distress, and create incentives for sound debt management in bankruptcy's shadow. ${ }^{2}$ Informal restructuring procedures are entrenched and well-known in a narrow circle of repeat players, but scattered across legal regimes and unintelligible to the public. National

\footnotetext{
${ }^{1}$ Jonathan Eaton \& Mark Gersovitz, Debt With Potential Repudiation: Theoretical and Empirical Analysis, 48 Rev. Econ. Stud. 289 (1981).

${ }^{2}$ Patrick Bolton \& David A. Skeel, Jr., Inside the Black Box: How Should a Sovereign Bankruptcy Framework Be Structured?, 53 Emory L.J. 763 (2004).
} 
regulation, ubiquitous in other areas of finance, is limited at best in sovereign debt, where market participants are presumed to be sophisticated and in no need of protection. Treaty-based institutions for rulemaking and adjudication, so salient in trade, are lacking in finance. ${ }^{3}$ Elsewhere in finance, transnational regulatory coordination has sought to fill the gaps in the formal treaty fabric; however, even as it has grown in the wake of financial crises, the regulatory machinery has bypassed sovereign debt. There are good reasons for excluding sovereign debt from each of these regulatory domains; however, the resulting regime is fraught with bad incentives and destructive outcomes.

Agency problems, time inconsistency, information asymmetries and moral hazard are perennial risks in sovereign lending and borrowing. Public officials borrow in the name of the people, but not in their interest. ${ }^{4}$ Future generations are saddled with unsustainable debts. Disclosure is faulty, particularly when it comes to contingent liabilities of the sovereign. ${ }^{5}$ Lenders who expect to be rescued by third-country taxpayers - or to be repaid before others of equal rank-keep credit flowing to insolvent debtors. ${ }^{6}$ When default comes, its worst effects fall on innocent bystanders, populations and future generations that had no say the borrowing decisions. Banking, currency, and political crises go hand in hand with sovereign debt default. ${ }^{7}$

The Principles on Promoting Responsible Sovereign Lending and Borrowing ("Principles") contribute to filling the legal and institutional void in three ways. First, they attempt to generalize and systematize from the law and practice of sovereign debt, to propose a unified normative framework for law-making in this area. Second, the Principles initiative aims to diffuse this knowledge, and broaden the consensus around what constitutes responsible behavior in sovereign finance. Third, the Principles engage diverse stakeholders to create constituencies for responsible practices.

Successful implementation of the Principles should result in a durable change of behavior among sovereign borrowers and their lenders. The goal is not a change in the law, but a shift in economic and social outcomes. Formal law reform can help, but is neither necessary nor sufficient to bring about such a shift.

\footnotetext{
${ }^{3}$ Chris Brummer, Why Soft Law Dominates International Finance-and not Trade 13 J.Int'I Econ.L. 623 (Oct. 2010).

${ }^{4}$ Symposium, Odious Debts and State Corruption, 70 Law \& Contemp. Probs., Summer 2007, at 1, 70 Law \& Contemp. Probs., Autumn 2007, at 1; Symposium, 32 N.C. J. Int'l L. \& Com. Reg. 605 (2007).

${ }^{5}$ Lee C. Buchheit \& Mitu Gulati, Restructuring a Sovereign's Contingent Liabilities (UNCTAD Working Paper, 2012).

${ }^{6}$ Patrick Bolton \& David A. Skeel, Jr., Inside the Black Box: How Should a Sovereign Bankruptcy Framework Be Structured?, 53 Emory L.J. 763 (2004).

${ }^{7}$ Carmen M. Reinhart \& Kenneth S. Rogoff, This Time Is Different: Eight Centuries of Financial Folly (2009).
} 
Four core characteristics of the Principles enhance the prospects of implementation defined in this way. First, the Principles do not claim to make new law, but rather to harness and elaborate existing best practices and general principles. ${ }^{8}$ Even where this claim has been questioned, the task of the Principles is one of adaptation, not invention. ${ }^{9}$ The core values and methods of the Principles are well-established in national legal systems. ${ }^{10}$ This should minimize the need for formal changes in national law, and the associated political and procedural obstacles to implementation.

Second, the Principles aspire to be comprehensive, inclusive and even-handed: they address both debtor and creditor practices and both public and private creditors across a broad range of instruments. They also contemplate an active role for civil society stakeholders. Other recent efforts to promote responsibility in international finance have focused on discrete sectors, practices, constituencies, and forms of finance. ${ }^{11}$ Partial regimes pose a greater risk of inequitable regulation and regulatory arbitrage. The Principles' ambitious reach promises to boost legitimacy and dissuade arbitrage in regulatory outcomes. By integrating diverse interests in a common program, the Principles also suggest input legitimacy, which should contribute to effective implementation.

Third, the process of drafting the Principles is another source of input legitimacy. They are a product of broad-based consultations with diverse governments, multilateral institutions, civil society groups, market associations, and legal and economic experts. Maintaining these links as the content of the Principles is elaborated and specified should enhance buy-in among the actors ultimately responsible for implementation.

Fourth, by improving risk management and accountability in sovereign finance, the Principles should become a force for financial stability. They contribute to crisis prevention by focusing on due diligence, transparency, and clear lines of authority ex ante. The Principles should improve the handling of sovereign debt distress by identifying the locus and standards of responsibility ex post. The Principles' emphasis on disclosure should facilitate constructive operation of market mechanisms at all stages of sovereign debt management. Together, these features contribute to the output legitimacy of the Principles, which should build support for sustained implementation and diffusion.

\footnotetext{
${ }^{8}$ Principles; Esposito \& Bohoslavsky (2012).

${ }^{9}$ Matthias Goldmann, Responsible Sovereign Lending and Borrowing: The View from Domestic Jurisdictions (UNCTAD Working Paper, 2012).

${ }^{10}$ Lee C. Buchheit, G. Mitu Gulati \& Robert B. Thompson, The Dilemma of Odious Debts, 56 Duke L.J. 1201 (2007).

${ }^{11}$ See Part II infra.
} 
Mindful of these strengths, I propose a three-prong implementation strategy: locking in the gains, establishing foundations for institutionalization, and building enduring constituencies for implementation.

The first prong of the strategy requires locking in the gains already embodied in the Principles, with public endorsement by key groups of stakeholders: states, civil society groups, and market participants. This can be done without altering the soft law character of the Principles. At the outset, it is important to cement and broaden public "buy-in" for the essential goals and core values of the Principles. Without a signal of broad-based ownership, the initiative may come to be portrayed as ineffectual or partisan. A diverse group of endorsers defines the Principles' ambitious constituency, and demonstrates demand for regulation ${ }^{12}$ in this area.

In contrast, attempting to negotiate a formal treaty based on the Principles is both infeasible and undesirable at this stage. It is infeasible because treaty negotiation and ratification would take many years - putting off the task of implementation into the far future-and might result in weaker substantive commitments. ${ }^{13}$ The treaty form cannot bind nonstate actors, such as private creditors, except by the consent of their states. ${ }^{14}$ As a result, a treaty may detract from the horizontal, multi-stakeholder character of the Principles that is their principal strength. No alternative formal commitment vehicle is available to bind diverse public and private actors under international law. Even if it were possible, formalization may be undesirable at this stage. It would risk freezing the current limited consensus and stymie further development of the Principles to reflect rapid changes in the financial markets and political participation. ${ }^{15}$ Paradoxically, early formalization may weaken the compliance pull of the Principles by shifting resources away from generating information and improving organizational practices, to

\footnotetext{
${ }^{12}$ Walter Mattli \& Ngaire Woods, In Whose Benefit? Explaining Regulatory Change in Global Politics, in THE PoLITICS OF Global Regulation (Walter Mattli \& Ngaire Woods, Eds., 2009).

${ }^{13}$ For example, work on the Convention on the Succession of States in Respect of State Property, Archives and State Debts began in 1967. The convention opened for signature in 1983, but is yet to enter into force. See United Nations Diplomatic Conferences, Convention on the Succession of States in Respect of State Property, Archives, and state Debts, at http://untreaty.un.org/cod/diplomaticconferences/succ-stateprop-archivesdbt-1983/succ-stateproparchivesdbt-1983.html (last visited February 20, 2012); Economic Aspects of State Succession: Final Report, International Law Association Toronto Conference (2006).

${ }^{14}$ Kenneth W. Abbott \& Duncan Snidal, Strengthening International Regulation Through Transnational New Governance: Overcoming the Orchestration Deficit, 42 Vand. J. Transnat'I L. 501 (2009).

${ }^{15}$ Potentially a more flexible "hard law" implementation strategy, which relies on judicial enforcement and the Principles' status as general principles of international law, is promising, but risky if pursued in isolation. Unfavorable court rulings may set back implementation, while a litigation-focused approach would mobilize interest groups and legal strategies opposed to the Principles. See Matthias Goldmann, Responsible Sovereign Lending and Borrowing: The View from Domestic Jurisdictions (UNCTAD Working Paper, 2012) and discussion in Part I.A infra.
} 
sanctioning bad behavior ${ }^{16}$ in an area where information is scarce, political tensions run high, and consensus on what constitutes compliance is only emerging.

The second prong of the implementation strategy would leverage support for the overall approach of the Principles, as evidenced by early endorsements, to begin institutionalization. Again, this does not require "hard law" or treaty-based organizations. Instead, the focus should be on designing institutions to supply an open, accountable regulatory process and mobilizing constituencies to demand disclosure, monitoring and assessment. Making information on sovereign lending and borrowing publicly accessible should enhance democratic accountability and market discipline alike. Creating institutions for monitoring information and fostering competition among them, can help develop expertise, entrench good practices, and create conditions for continuous improvement. ${ }^{17}$ Put differently, successful implementation of the Principles requires technology to disseminate information about sovereign lending and borrowing, and people with the skills and incentives to collect, distribute, and interpret such information. Both the monitored and the monitors are pushed to do better when there is a robust information flow, and competition to provide credible and transparent assessment of the information. Monitoring mechanisms may be stand-alone and brand new, part of existing public, private or civil society institutions, or a combination.

Third, successful implementation of the Principles requires constituents with a stake in compliance. ${ }^{18}$ Constituents can emerge in an iterative process of elaborating and refining the Principles, and assessing compliance. Interpretation and revision of the Principles to reflect the evolving economic and political context, as well as implementation experience, should foster durable "ownership" of the Principles among different stakeholders. Although interpretation and revision institutions should be inclusive, they need not be centralized. Decentralization can preserve the space for generating and contesting ideas ${ }^{19}$ about regulation of sovereign lending and borrowing, and also enhance legitimacy. Local, regional, and interest group bodies may be most effective in channeling different constituents' concerns, so long as there is an effective coordination mechanism among them. On the down side, multiple interpretation and

\footnotetext{
${ }^{16}$ (data from environmental regulation suggests that coercive state sanctions weaken compliance with self-regulatory commitments, but robust regulatory surveillance improves it).

${ }^{17}$ Charles Sabel, Dara O'Rourke \& Archon Fung, Ratcheting Labor Standards: Regulation for Continuous Improvement in the Global Workplace, KSG Working Paper No. 00-010; Columbia Law and Economic Working Paper No. 185; Columbia Law School, Pub. Law Research Paper No. 01-21, May 2000, available at http://ssrn.com/abstract=253833 or http://dx.doi.org/10.2139/ssrn.253833.

${ }^{18}$ This is related to the concept of demand for regulation; however, constituents can also include "suppliers" such as rulemaking and monitoring institutions. Walter Mattli \& Ngaire Woods, In Whose Benefit? Explaining Regulatory Change in Global Politics, in The Politics of Global Regulation (Walter Mattli \& Ngaire Woods, Eds., 2009).

${ }^{19}$ Id.
} 
assessment bodies can produce fragmentation and confusion, opening opportunities for arbitrage. This is an argument for more centralization and even a hierarchy of interpretation.

Throughout, it is important to consider the relationship of the Principles to the existing machinery of "hard law" - international organizations, national regulators, national and international dispute resolution fora, treaties, and contracts-as well as the established "soft" infrastructure for cooperation, including the G-20 and the FSB. ${ }^{20}$ Linking the Principles to existing mechanisms taps into established institutional supply, promote their institutional embeddedness, and make them part of the fabric of international law and financial regulation. Whether this leads to a "hardening" of the Principles into custom, treaty, or other formal and binding law, and to the creation of new formal institutions, is a question for another day. Implementation need not wait until then.

The remainder of this paper proceeds as follows. In Part I, I put the Principles in the context of sovereign debt governance and international economic regulation. I describe the work of hard law, soft law, and new governance in sovereign debt. Part II surveys experience from recent initiatives to govern aspects of the international financial system, including project finance, extractive industries, foreign aid, sovereign investment, and capital markets borrowing. I also consider the evolution of anticorruption law from soft initiative to multilateral treaty. Although these experiences offer valuable lessons, none serves as direct precedent for the Principles. Part III synthesizes the theoretical literature and the experiences described in Part II to offer recommendations for implementation.

As the first step, I suggest securing the endorsement of governments, but just as importantly, market and civil society groups in the run-up to Doha. It is important to secure endorsements from different regions and parts of the national income spectrum. These should be unequivocal with respect to the overarching goals and methods of the Principles, but need neither adopt nor exclude specific principles and their implications. I recommend simultaneously reaching out to existing public fora, including IMF, FSB, BIS, and the Paris Club, some of which have been involved in the creation of the Principles, to explore incorporation in surveillance, technical assistance, and other aspects of their operations. Trade associations, such as ICMA, SIFMA, and IIF, should be consulted for endorsement, but also to explore linkages with their best practice guidance and monitoring mechanisms. National debt management agencies can be tapped to

${ }^{20}$ Chris Brummer, Soft Law and Global Financial System: Rule Making in the $21^{\text {St }}$ Century (2012). 
consider incorporating the Principles in their debt contracts ${ }^{21}$ and operational practices. Second, civil society groups, academics, and market participants should be encouraged to design monitoring and assessment mechanisms and publicize their proposals. ${ }^{22}$ Finally, I recommend forming a Principles governance body to coordinate disclosure, monitoring, interpretation and elaboration issues. The body should meet regularly and report to UNCTAD - which would assume an "orchestration" role in support of informal regulation ${ }^{23}$-but also to the public on a dedicated website. Among other tasks, it should synthesize the compliance metrics developed by civil society, academic, market, and official participants, promote coordination among constituents, evaluate implementation, and support the adaptation of the Principles to ensure their continued relevance.

\section{Part I: Hard Law, Soft Law, and New Governance in Sovereign Debt}

\section{A. Hard Law in Sovereign Debt}

At this writing, sovereign debt stands at over $\$ 40$ trillion. ${ }^{24}$ Considering its size, national and global importance, and the multitude of diverse international actors in this market, the apparent dearth and fragmentation of law in it is remarkable. In one sense, this state of affairs is par for the course in international finance. Scholars often contrast international finance-governed informally, through coordination networks among national regulators-and international trade, where formal and binding treaties and

\footnotetext{
${ }^{21}$ See Eric Helleiner, Filling a Hole in Global Financial Governance? The Politics of Regulating Sovereign Debt Restructuring in The Politics of Global Regulation (Walter Mattli \& Ngaire Woods, Eds., 2009) (reporting on the successful reform of boilerplate sovereign debt contracts as an instance of entrepreneurial regulation). But see $\mathrm{W}$. Mark C. Weidemaier, Reforming Sovereign Lending Practices: Modern Initiatives in Historical Context (Working Paper 2012, suggesting that government efforts to prompt private contract reform have been ineffective or have brought about unforeseen results).

${ }^{22}$ Funding options may need to be considered to encourage effective civil society input.

${ }^{23}$ Kenneth W. Abbott \& Duncan Snidal, Strengthening International Regulation Through Transnational New Governance: Overcoming the Orchestration Deficit, 42 Vand. J. Transnat'I L. 501 (2009) (describing the orchestration function and "orchestration deficit" in transnational governance).

${ }^{24}$ Estimate based on BIS Securities Statistics, December 2011, Tables 12D (September 2011), 16A (June 2011) and Joint External Debt Hub data. The vast majority of this debt comprises domestic instruments issued by wealthy states in the capital markets. External debts owed by low and middle-income countries, and debts owed to bilateral and multilateral lenders, account for a small part of the total. In recent years, the boundaries between domestic and external debts, public and private creditors, have blurred: foreign residents participate in domestic debt markets, and central banks and sovereign investment funds are important creditors to foreign governments.
} 
institutional structures of the World Trade Organization prevail. ${ }^{25}$ But sovereign debt is exceptional even within international finance.

Private financial institutions and capital markets are subject to formal regulation at the national level, coordinated in fora such as the Basel Committee for Bank Supervision, and more recently, the Financial Stability Board. Market participants' contracts are routinely enforced in domestic courts. When they become insolvent, most can avail themselves of statutory bankruptcy or resolution procedures, which in turn create incentives for debt management in good times.

Virtually none of these features are present in sovereign debt. Sovereign immunity and the difficulty of reaching sovereign assets make debt contract enforcement unpredictable. ${ }^{26}$ Some countries refuse to abide by repayment promises - yet others are forced to repay when they cannot and should not. ${ }^{27}$ There is no bankruptcy procedure for sovereigns. ${ }^{28}$ Debt adjustment takes place in a constellation of informal processes dominated by elite insiders, as discussed in more detail in the next section. From regulators' perspective, sovereign debt markets are generally the province of sophisticated issuers and investors, who need little by way of consumer protection. ${ }^{29}$ As a result, sovereign debt is not just a zone where treaties, custom, and adjudication ${ }^{30}$ are rare-it appears to be a law-free zone.

To be sure, most countries have laws and institutions governing their own debt issuance; courts do occasionally rule on foreign sovereign debt contract disputes; and

\footnotetext{
${ }^{25}$ See e.g., Chris Brummer, Why Soft Law Dominates International Finance-and not Trade 13 J.Int'l Econ.L. 623 (Oct. 2010).

${ }^{26}$ The immunity is codified in many jurisdictions, including the United States and the United Kingdom. Foreign Sovereign Immunities Act of 1976, 28 U.S.C. § 1605(a)(2) (2006); State Immunity Act 1978, 1978 Chapter 33, available at http://www.legislation.gov.uk/ukpga/1978/33. This enforcement challenge is at the heart of economic theories about sovereign debt. See Jonathan Eaton \& Mark Gersovitz, Debt With Potential Repudiation: Theoretical and Empirical Analysis, 48 Rev. Econ. Stud. 289 (1981); see also Federico Sturzenegger \& Jeromin Zettelmeyer, Debt Defaults AND LESSONS FROM A DECADE OF CRISES 31-47 (2007) (summarizing the literature). Litigation in the wake of Argentina's 2001 default is illustrative: the only creditor attachment came nearly a decade after the initial default, and involved obscure debates about trust law. EM, Ltd. v. Republic of Argentina, NML, Ltd., v. Republic of Argentina, 2009 WL 2568433 (August 18, 2009), EM, Ltd. v. Republic of Argentina, 389 Fed. Appx. 38 (2d Cir., August 3, 2010), cert. denied 131 S.Ct. 1474 (February 22, 2011). See also Alison Frankel, U.S. Walks Dangerous Line to Support Argentina in Bond Cases, Thompson Reuters, Apr. 9, 2012, available at http://newsandinsight.thomsonreuters.com/Legal/News/ 2012/04_-_April/U_S_walks_dangerous_line_to_support_Argentina_in_bond_cases/ (U.S. position in the latest round of creditor lawsuits against Argentina undermines already weak sovereign debt enforcement).

${ }^{27}$ See e.g., Donegal Int'I Limited v. Republic of Zambia [2007] EWHC197 (Comm).

${ }^{28}$ For an account of the most recent attempt to establish a statutory sovereign bankruptcy regime, see Sean Hagan, Designing a Legal Framework To Restructure Sovereign Debt, 36 Geo. J. Int'I L. 299.

${ }^{29}$ Cases where retail investors are a big factor are rare - Argentina's default in 2001 was exceptional for involving numerous retail investors in Italy.

${ }^{30}$ For the widely accepted statement of the sources of "hard" law, see Statute of the International Court of Justice art. 38, Oct. 24, 1945, 832 U.S.T.S.
} 
some national laws attempt to influence foreign sovereign debt practices. ${ }^{31}$ There have been treaty initiatives to govern aspects of the market. ${ }^{32}$ The steady evolution of sovereign immunity doctrines and, at the other end of the spectrum, the recentlyrevived debate about Odious Debt, testify to the potential of customary international law in this area. ${ }^{33}$ However, such examples stand out as exceptions: they are few, and have a limited or contested record of implementation.

Scholars have considered why formal and binding international law plays such a limited role in international finance. ${ }^{34}$ Some of their explanations apply to sovereign debt. Treaties take a long time to negotiate; may be diluted outright and through piecemeal reservations; and are hard to amend-though amenable to exit. ${ }^{35}$ They seem ill-suited for a field characterized by the speed of technological and financial innovation. ${ }^{36}$ By some accounts, customary international law is even more problematic for its combination of uncertainty and inflexibility. Custom can take a long time to emerge; the precise content and moment of its emergence are uncertain; and changing or opting out of custom is even harder than changing treaties. ${ }^{37}$ None of these reasons would rule out recourse to treaties and custom as means of implementing the Principles, but at a minimum, they suggest caution in relying on these mechanisms as principal vehicles for implementation.

Different concerns apply to another potential avenue for hard international law: locating responsible lending and borrowing in "the general principles of law recognized by civilized nations." ${ }^{38}$ Where such shared principles apply, courts are bound by them as by other sources of international law. Extrapolating to Principles implementation, to the extent they are found to reflect widely accepted domestic law, courts may be asked to apply them as such. As a source of hard sovereign debt law, general principles raise three challenges: identification, fragmentation, and constituency-building. Identifying

\footnotetext{
${ }^{31}$ See e.g., the UK Debt Relief (Developing Countries) Act 2010, available at http://www.legislation.gov.uk/ ukpga/2010/22/contents.

32 UNCTAD initiatives in the 1960 s and 1970 s are a prominent example. For a description, see LEX RIEFFEL, RESTRUCTURING Sovereign Debt: The CASE for Ad Hoc Machinery 132-148 (2003); see also Hagan, supra note 23.

${ }^{33}$ Sabine Michalowski, Unconstitutional Regimes and the Validity of Sovereign Debt: A Legal Perspective 33-96 (2007)

${ }^{34}$ For a comprehensive account of the soft governance of international finance, see Chris Brummer, Soft Law and Global Financial System: Rule Making in the $21^{\text {st }}$ Century (2012); for a critique of the predominant explanations of the softness, see Pierre-Hugues Verdier, Why Regulate International Finance? (Working Paper 2012).

${ }^{35}$ Laurence R. Helfer, Exiting Treaties 91 VA L. Rev. 1579 (2005).

${ }^{36}$ Roberta S. Karmel \& Claire R. Kelly, The Hardening of Soft Law in Securities Regulation, 34 Brook.J.Int'IL., 883, 885 (2009).

${ }^{37}$ Curtis Bradley \& Mitu Gulati, Opting Out of Custom 120 Yale L. J. 202 (2010); Andrew Guzman, Saving Customary International Law, 27 Mich. J. of Int'l L. 115 (2005).

${ }^{38}$ Statute of the International Court of Justice art. 38(1)(c), Oct. 24, 1945, 832 U.S.T.S. Similarly, the Restatement of the Foreign Relations Law of the United States (Third) (1987), Sec. 102, refers to "[g]eneral principles common to the major legal systems." See Malcolm N. ShaW, International LaW 98-105 (2008); Armin von Bogdandy, General Principles of International Public Authority: Sketching a Research Field, 9 German L. J. 1909 (2008).
} 
general principles can become a complex inquiry of comparative law. Where the inquiry is inconclusive or jurisdictions differ, courts may shy away from applying the law, or may apply it narrowly. ${ }^{39}$ An academic study of fifteen jurisdictions undertaken in connection with Principles implementation concludes that while many of the Principles are generally accepted, others reflect and adapt current trends. ${ }^{40}$ It follows that an implementation argument based on general principles would be more successful with respect to some of the Principles than others, and in some courts more than in others, potentially contributing to the fragmentation of sovereign debt law. Finally, governing sovereign debt from "hard" general principles relies importantly on litigation. In this context, some powerful interest groups will invest in legal strategies against hardening standards of responsibility. At a minimum, if such groups are also involved in the multistakeholder implementation strategies discussed in Part III, they may find it more difficult to litigate in opposition.

Finally, hard law faces structural fit problems in sovereign finance, most of which is built on horizontal contracting between private creditors and states as market participants. While national law may face enforcement constraints when applied to sovereigns, hard international law does not comprehend states and nonstate actors in a horizontal relationship. A state may enter into a treaty to bind itself and its subjects; industry and NGO representatives may influence a state's position in treaty negotiations; states may even establish hybrid tribunals; ${ }^{41}$ however, in all these arrangements, nonstate participants enter indirectly and courtesy of their states.

The dearth of hard law in sovereign debt may have an optimistic explanation: the current constellation of formal institutions and informal practices, including the IMF, the World Bank, and the Paris Club, described in the next section, do a fine job of managing the space. A more skeptical view might be that the informal and ad-hoc approach maximizes policy flexibility for the strongest private and state creditors at the expense of weaker actors. ${ }^{42}$

\footnotetext{
${ }^{39}$ Rosa Ehrenreich Brooks, Law in the Heart of Darkness: Atrocity and Duress, 43 VA J. Int'I L. 861 (2003) (discussing judicial treatment of general principles in a case where a survey of fifteen jurisdictions determined that civil and common law jurisdictions differed); see also Judgment, Prosecutor v. Erdemovic, Case No. IT-96-22-A (I.C.T.Y., Appeals Chamber, Oct. 7, 1997), available at http://www.un.org/icty/erdemovic/appeal/judgement/erd-aj971007e.htm .

${ }^{40}$ Matthias Goldmann, Responsible Sovereign Lending and Borrowing: The View from Domestic Jurisdictions (UNCTAD Working Paper, 2012). Most of the general principles concerned were not limited to sovereign debt, but rather debt and financial responsibility more broadly.

${ }^{41}$ The International Centre for Settlement of Investment Disputes is an example. www.icsid.worldbank.org.

${ }^{42}$ See Eric Helleiner, Filling a Hole in Global Financial Governance? The Politics of Regulating Sovereign Debt Restructuring in The Politics of Global Regulation (Walter Mattli \& Ngaire Woods, Eds., 2009) (describing how NGOs were outmaneuvered by creditor groups and creditor country governments). Compare Pierre-Hugues Verdier, Why Regulate International Finance? (Working Paper 2012).
} 
In sum, the role of formal domestic and international law in the sovereign space is limited. Even if it were easy to negotiate a treaty or spur the formation of custom in this field, it is likely to be an awkward fit. Relying solely on general principles of law in sovereign debt may contribute to fragmentation, and mobilize litigation strategies against standards of responsibility. The next two sections investigate soft law and new governance approaches to sovereign debt.

\section{B. Soft Law in Sovereign Debt and International Financial Regulation}

Soft law hovers between hard law and aspiration. Although definitions abound, most focus on the absence or weakness of legal obligation, and on informality. ${ }^{43}$ For some international law scholars, soft law hardly adds up to law at all. ${ }^{44}$ Others appreciate its capacity to secure compliance by other means, and suggest that it may be as good as hard law in most pertinent respects-at least in international finance. ${ }^{45}$ Examples of soft law in international finance range from high level commitments of the G-7 and the G-20, to the rulemaking of the Basel Committee and the Financial Stability Board. None is formally binding, each exerts compliance pull.

In sovereign debt, the role of soft law is readily apparent in the prevailing system for dealing with debt distress. Traditionally, a country that has trouble paying its foreign debts might approach the IMF for financing. In most cases, such financing would be conditional on implementation of economic reforms, designed among other things to ensure that the Fund is repaid. The resulting economic program would include an assessment of debt sustainability and financing need during the program period. To fill the "financing gap," the country would next go to the Paris Club, where creditor states will negotiate relief of bilateral debts, usually based on one of a menu of formulas. They would then send the country to obtain "comparable" terms from other creditors, including private commercial banks and bondholders. ${ }^{46}$

Figure 1 is a stylized representation of the external sovereign debt restructuring process. Bordered shapes stand for entities with legal personality under domestic or international law. Although the protagonists in the process are states, international organizations, and firms, the process itself-in the middle row-is overwhelmingly soft.

\footnotetext{
${ }^{43}$ Andrew Guzman, The Design of International Agreements, 16 EJIL 579, 583-584 (2005).

44 Jean d'Aspremont, Softness in International Law: A Self-Serving Quest for Legal Materials, 19 EJIL 1075 (2008); Anthony D'Amato, Softness in International Law: A Self-Serving Quest for Legal Materials: A Reply to Jean d'Aspremont, 20 EJIL 897 (2009); Jean d'Aspremont, Softness in International Law: A Self-Serving Quest for Legal Materials: A Rejoinder to Tony D'Amato, 20 EJIL 911 (2009).

${ }^{45}$ Chris Brummer, Soft Law and Global Financial System: Rule Making in the $21^{\text {ST }}$ Century (2012).

46 The Paris Club, What Does Comparability of Treatment Mean?, available at http://www.clubdeparis.org/ sections/composition/principes/comparabilite-traitement/switchLanguage/en (last visited on February 20, 2012).
} 
Fig. 1:

Informality and Fragmentation in Sovereign Debt Restructuring

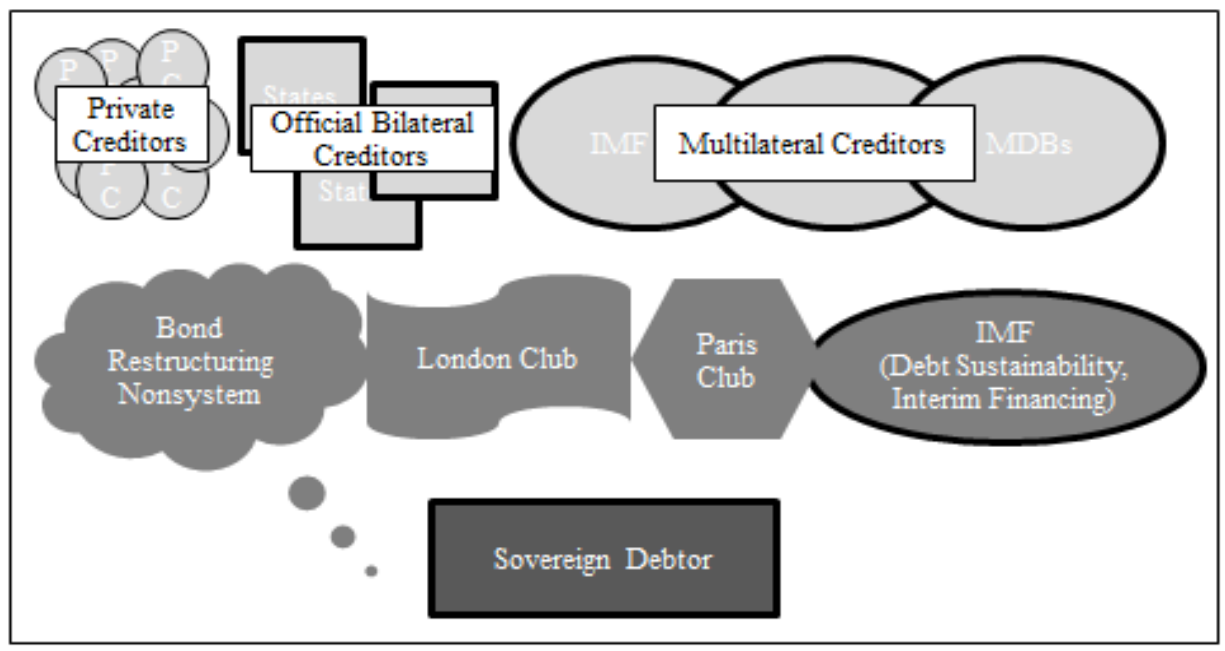

The Paris Club and the London Club are informal coordination mechanisms with no legal personality. They mediate between the sovereign and its creditors. The Paris Club emerged as a forum for official bilateral creditors in the mid-1950s; it meets regularly at the French finance ministry to negotiate debt restructuring terms for government-togovernment debt. Although its procedures and outcomes are quite regimented, the Paris Club has no charter and no personality under domestic or international law, and has only recently launched a website. ${ }^{47}$ The London Club is even less formal. The term refers to a system of bank advisory committees that renegotiated syndicated loan contracts with low and middle-income sovereigns during the debt crisis of the 1980s. Although the workings of the London Club, like the Paris Club, are reasonably predictable, it has no permanent home, secretariat, or website. ${ }^{48}$ The bond restructuring "nonsystem" came to the forefront of sovereign debt management in the 1990s. Although it features a certain repertoire of restructuring tools, ${ }^{49}$ the system lacks the institutional structure of the other fora. It is essentially a subset of capital markets transactions. Multilateral creditors traditionally have been excluded from restructuring,

\footnotetext{
${ }^{47}$ The timing is ironic: the Paris Club became more transparent just as its relevance in international debt matters was beginning to decline in the wake of deep debt reduction initiatives that ended some countries' iterative relationship with the club.

${ }^{48}$ Alfred Mudge, Sovereign Debt Restructure: A Perspective of Counsel to Agent Banks, Bank Advisory Groups and Servicing Banks, 23 Columbia J. of Transnat'I L. 59 (1984).

${ }^{49} \mathrm{Ran} \mathrm{Bi}$, Marcos Chamon, \& Jeromin Zettelmeyer, The Problem that Wasn't: Coordination Failures in Sovereign Debt Restructurings, IMF Working Paper WP/11/265 at 7-8 (Nov. 2011) (describing sovereign bond exchange techniques) at http://www.imf.org/external/pubs/ft/wp/2011/wp11265.pdf.
} 
though they have scrupulously avoided claiming formal preference. ${ }^{50}$ Initiatives for poor heavily indebted countries launched in the late 1990s are a partial exception to this treatment.

The sovereign debt restructuring process is routinized and well-known to countries and institutions that participate (many repeatedly), financial firms active in the sovereign debt market, and a tight-knit cadre of lawyers in New York and London. However, to the outsider-including citizens of debtor and creditor countries-it is largely unknown, unintelligible, and potentially illegitimate. The system is hierarchical ${ }^{51}$ and far from comprehensive. Already convoluted, Figure 1 would become hopelessly cluttered if regional authorities, trade creditors, suppliers, and domestic creditors-all of whose claims are addressed separately-were added in.

The record of this system in delivering debt relief, and more importantly, fostering responsible borrowing and lending ex ante, is vigorously contested. Some writers point to the dozens of cases where countries obtained deep debt relief without formal bankruptcy procedures as prima facie evidence of success. Yet others focus on the inadequate volume and slow provision of relief, and the persistence of problematic debt accumulation as evidence of system failure. Like most soft law systems, sovereign debt restructuring has shown flexibility over time-visible in the evolution of Paris Club membership and terms, the incorporation of bond restructuring techniques, and the introduction of multilateral debt relief in response to civil society initiatives-however, it has also suffered from deficits of transparency, democratic accountability, and efficacy.

It is useful to compare briefly the workings of soft law in sovereign debt and other areas of international finance. The existing literature on soft law in international finance is dedicated almost entirely to international financial regulation (IFR). On the whole, the assessment of soft law's role in IFR is positive, although the financial crisis has tempered some of the enthusiasm. ${ }^{52}$

\footnotetext{
${ }^{50}$ Rutsel Silvestre J. Martha, Preferred Creditor Status under International Law: The Case of the International Monetary Fund, 39 Int'I \& Comp. L.Q. 801 (1990).

${ }^{51}$ Debtor agency in the process is limited, defined essentially by the government's willingness to default. In 2000, efforts by private creditors to secure "reverse comparability" - or press the Paris Club into debt restructuring on private creditors' terms - were decisively rebuffed. See, e.g., Jorge Gallardo, Cracks in the New Financial Architecture, Euromoney, Apr. 2001, at 50.

${ }^{52}$ David Zaring, International Institutional Performance in Crisis, 10 Chi. J. Int'I L. 475 (2010).
} 
Proponents describe soft lawmaking as more expert, flexible, and efficient; more cooperative and less threatening to regulatory sovereignty than old-style hard law. ${ }^{53}$ With these advantages, soft law operating through transnational networks has blossomed, and has begun to develop a record of accomplishment in coordinating regulatory enforcement and harmonizing certain regulatory standards. ${ }^{54}$ States adopt and implement the strictures of Basel capital accords, collaborate in enforcing securities laws, and fight money laundering even though (or precisely because) no one forced them to. In this telling, networks of similarly minded regulators ${ }^{55}$ have succeeded where generations of diplomats have come up short.

This joyful take on transnational regulation has always had its critics, and has come under intense scrutiny in the aftermath of $2008 .{ }^{56}$ Today's view of soft law is less inclined to presume cooperation and community of interest. It allows that national regulators may seek to promote domestic competitiveness ahead of regulatory harmony, resist the high domestic costs of adhering to global rules, and may pursue "mock compliance" to mask substantive divergence. ${ }^{57}$ The task is to explain what substantive compliance takes place despite these pressures. ${ }^{58}$ But even where the system achieves compliance, problems remain. IFR networks are hardly comprehensive; IFR's strengths-decentralization and horizontality-also make it prone to arbitrage and capture. And the flipside of cooperative epistemic communities of regulators ${ }^{59}$ is regulatory "groupthink," which can magnify and spread individual regulatory errors in crisis. $^{60}$ Perhaps most importantly, an informal technocratic system deliberately insulated from politics is constantly defending its democratic legitimacy.

\footnotetext{
${ }^{53}$ This is a functionalist set of explanations for the success of soft law in international finance. A constructivist approach might emphasize socialization into compliance.

${ }^{54}$ Kal Raustiala, Transnational Networks: Past and Present, 43 Int'l L. 205 (2009); David Zaring Three Challenges for Regulatory Networks 43 Intl L. 211 (2009). Compare Pierre-Hugues Verdier, Why Regulate International Finance? (Working Paper 2012).

${ }_{55}^{5}$ AnNe-Marie Slaughter, A New World Order (2003).

${ }^{56}$ See e.g., Pierre-Hugues Verdier, Transnational Regulatory Networks and Their Limits, 34 Yale J. Int'I L. 113 (2009); David Zaring, International Institutional Performance in Crisis, 10 Chi. J. Int'I L. 475 (2010); CHRIS BRUMmER, SOFt LAW AND Global Financial System: Rule Making In the $21^{\text {ST Century }} 263$ (2012): “[T] he Basel process ... viewed until recently as the apogee of international financial cooperation, has consistently failed to prevent bank failures and global economic crises, even with its ostensibly more stringent rules."

${ }^{57}$ Andrew Walter, Governing Finance: East Asia's Adoption of International Standards 171 (2008).

${ }^{58}$ Pierre-Hugues Verdier, Why Regulate International Finance? (Working Paper 2012) at 17-25 and sources cited (literature survey).

${ }^{59}$ See e.g., Peter M. Haas, ed, Introduction, Epistemic Communities and International Policy Coordination, 46 Int'l Org. 1 (1992).

${ }^{60}$ Chris Brummer, Soft Law and Global Financial System: Rule Making in the $21^{\text {ST }}$ Century 220-233 (2012).
} 
Many of these criticisms of IFR parallel criticisms of the soft system for sovereign debt restructuring earlier in this section. Some scholars of soft law have taken these shortcomings of IFR as a basis to prescribe hard law. For skeptics, soft law may be structurally incapable of raising regulatory standards and generating credible commitments. Soft law works best to promote liberalization and enforcement cooperation, both of which serve the interests of dominant actors in the global economy, rich states and large financial firms. Soft law's dominance of IFR may just be a byproduct of power politics and regulatory capture. ${ }^{61}$ If this argument is right, the IFR experience is a cautionary tale for Principles implementation.

On the other hand, the flaws of soft law are not in themselves a robust argument for hard law. The alternative to soft law in many instances is not a WTO-style regime, but a vacuum of legality. If the policy objective is better standards and deeper compliance, it makes sense to revisit in more detail the mechanics that make soft law bind.

Two broad categories of tools that promote compliance with soft law in IFR hold promise for Principles implementation. The first of these is disclosure and reporting, which can be leveraged to enhance reputational sanctions and market discipline. ${ }^{62}$ Second, institutional linkages can help anchor new and developing soft law in established legal regimes, soft and hard, domestic and international. The two categories are complementary; the second may blend soft and hard law approaches. In the first instance, nonbinding commitments are embedded in monitoring and reporting procedures. Monitoring and reporting may be linked to more formal surveillance by existing institutions, such as the IMF, the development banks, and the various regulatory fora. The initial standards may be refined, elaborated and revised in the course of periodic surveys of "core principles" and "best practices." Divergence from the standards may be subject to hard and soft sanctions, including name-and-shame strategies, conditionality, market exclusion, and abridgement of membership privileges in the various fora. ${ }^{63}$ Although the most potent sanctions may be difficult to invoke and sustain, their ultimate availability and potential linkages among them exert a measure of discipline.

\footnotetext{
${ }^{61}$ Pierre-Hugues Verdier, Why Regulate International Finance? (Working Paper 2012). The debate about the efficacy of soft law in international finance mirrors similar debates in national and transnational regulation. See, e.g., literature surveys in Jodi Short \& Michael W. Toffel, Making Self-Regulation More Than Merely Symbolic: The Critical Role of the Legal Environment, 55 Admin Sci. Q. 361-396 (2010) and Walter Mattli \& Ngaire Woods, In Whose Benefit? Explaining Regulatory Change in Global Politics, in The Polttics of Global Regulation (Walter Mattli \& Ngaire Woods, Eds., 2009).

${ }^{62}$ Verdier observes that market discipline cuts both ways. Pierre-Hugues Verdier, Why Regulate International Finance? (Working Paper 2012).

${ }^{63}$ Chris Brummer, Soft Law and Global Financial System: Rule Making in the $21^{\text {ST }}$ Century 147-156 (2012).
} 
In sum, the debate about soft law in IFR is instructive for efforts to reform sovereign borrowing and lending. Soft law prevails in both fields, along with its collateral benefits and challenges: flexibility and potential for horizontality, but also uncertainty, incompleteness, fragmentation, lack of transparency and accountability. While the parallels between IFR and sovereign debt should not be overstated (for one, sovereign debt is very thinly regulated), some of the tools that promote compliance in IFR hold promise for the implementation of the Principles. In the next section, I briefly consider these tools from the perspective of the literature on new governance, which helps enrich explanations of their effectiveness.

\section{The New Governance Dimension}

Contemporary scholarship on soft law in finance is anchored in debates about sources and compliance in public international law and international relations. Soft law also plays an important role in the literature on new governance, which emerged in the 1990 s as an alternative vision of domestic administrative regulation. ${ }^{64}$

The core normative insight of new governance is that an open and collaborative approach to regulation-where subjects participate in lawmaking alongside government agents-produces better law and improved compliance. In this view, successful regulation is open-ended, to allow elaboration over time, iterative, to foster information flow and participatory law-making, and accountable, with all stakeholders responsible for the outcome. 65 "Soft" codes, consultation and monitoring arrangements are

\footnotetext{
${ }^{64}$ But see The Politics of Global Regulation (Walter Mattli \& Ngaire Woods, Eds., 2009); Kenneth W. Abbott \& Duncan Snidal, Strengthening International Regulation Through Transnational New Governance: Overcoming the Orchestration Deficit, 42 Vand. J. Transnat'I L. 501 (2009) (adapting domestic new governance theory for transnational regulation). See also Kenneth W. Abbott \& Duncan Snidal, The Governance Triangle: Regulatory Standards Institutions and the Shadow of the State in The Politics of GLOBAL Regulation (Walter Mattli \& Ngaire Woods, Eds., 2009).

${ }^{65}$ Cristie L Ford, New Governance, Compliance, and Principles-Based Securities Regulation, 45 Business Law Journal 1 (2008) at 5 (description of New Governance in finance). For theories of new governance and related perspectives, see Susan Sturm, A Normative Theory of Public Law Remedies, 79 Geo.L.J. 1355 (1991); IAN Ayres \& John Braithwalte, Responsive Regulation: Transcending the Deregulation Debate (1992); Jody Freeman, Collaborative Governance in the Administrative State, 45 UCLA L. Rev. 1 (1997); Michael C. Dorf \& Charles F. Sabel, A Constitution of Democratic Experimentalism, 98 Colum. L. Rev. 267 (1998); Charles F. Sabel \& William H. Simon, Destabilization Rights: How Public Law Litigation Succeeds, 117 Harv. L. Rev. 1016 (2004); Julia Black, Constructing and Contesting Legitimacy and Accountability in Polycentric Regulatory Regimes, 2 Regulation \& Governance 137 (2008). For different perspectives on the scholarly field, see Orly Lobel, The Renew Deal: The Fall of Regulation and the Rise of Governance in Contemporary Legal Thought, 89 Minn. L. Rev. 342 (2004) and Bradley Karkkainen, "New Governance" in Legal Thought and in the World: Some Splitting as Antidote to Overzealous Lumping, 89 Minn. L. Rev. 471 (2004); for an account situating new governance in the broader context of "new realism" scholarship, see Victoria Nourse \& Gregory Shaffer, Varieties of New Legal Realism: Can a New World Order Prompt a New Legal Theory?, 95 Cornell L. Rev. 61 (2009).
} 
common examples. Regulators might turn to this new approach for a number of reasons, including substantive conviction, limited public sector resources, or limited information about the regulated industry. Theory predicts that the approach should work because the resulting regulation is based on better information, and because regulatory subjects that help make the law are more likely to follow it.

Despite obvious overlaps, soft law and new governance are distinct. Soft law's softness stands in contrast to the formal attributes and binding force of treaties and custom. The novelty of new governance is in the process, emphasizing public-private collaboration, adaptive problem-solving, experimentalism, open-endedness, and shared accountability. Its foil is "command and control" regulation, where governments make fully articulated static rules, and enforce private actors' compliance with them. Soft law can be (but is not necessarily) an instrument of new governance-and new governance techniques can be important in promoting compliance with soft law. Flexibility, horizontal and decentralized law-making may be among the by-products and advantages of softness, but they are not universal, nor essential to its definition. ${ }^{66}$ For example, the prevailing regime for sovereign debt restructuring is certainly soft, but rarely horizontal. In contrast, such characteristics are at the heart of new governance. Linkages between soft law and hard institutions of the sort described in the preceding section are prominent in new governance methodology.

The distinct perspectives on accountability in soft law and new governance are revealing. In soft law, accountability-understood as law-making governments answering to the people-is a perennial challenge that attends informality and lawmaking by expert networks. New governance replaces the challenge with the concept of "decentralized accountability" - open, participatory law-making, where state and nonstate actors answer to one another. The ideal of legitimacy in new governance might be one where regulation is accepted as a shared community norm, internalized as "appropriate and justified" in the absence of top-down authority or sanction ${ }^{67}$

Legal scholarship in the field tends to be expressly prescriptive: arguing for or against the adoption of new governance models in lieu of, or to complement, traditional regulation. Other disciplines put more emphasis on identifying, classifying, and explaining the proliferation of governance initiatives. Scholars have found examples of new governance in labour, environmental, healthcare, corporate, criminal, and many

\footnotetext{
${ }^{66}$ These elements resonate with the constructivist view of soft law: law emerges from collaborative iteration, and socialization into shared values.

${ }^{67}$ Steven Bernstein \& Benjamin Cashore, Can Non-State Global Governance Be Legitimate? An Analytical Framework, 1 Regulation \& Governance 347 (2007) (putting forward a "logic of appropriateness" as an alternative source of legitimacy in non-state market driven governance systems, in contrast to the traditional "logic of consequences" in state regulation).
} 
other fields of law. These include stakeholder consultation requirements in rulemaking, codes of social responsibility, corporate monitors, and regulatory exemptions linked to internal procedures at private firms. Typologies and histories abound. Some accounts trace the progressive development of first-, second-, and third-person private regulation, from voluntary commitments at isolated firms, to industry-wide codes of conduct, to independent certification regimes. ${ }^{68}$ Others focus on actors, and the ways in which they come together to produce and implement regulation. Abbot and Snidal's "Governance Triangle" is an elaborate actor-centered representation of new governance by combinations of states, firms, and NGOs, occupying the triangle's vertices. ${ }^{69}$ In this view, some initiatives emerge from the combined efforts of firms and states, others from firms and NGOs, yet others from states and NGOs. Some, though not many, reside in the center of the triangle, channelling all three sets of actors.

The Principles fit comfortably on the new governance spectrum both for the collaborative process that produced them, as well as for their emphasis on common interests and non-coercive implementation. On the other hand, they are somewhat atypical for the literature, because in sovereign borrowing and lending, states appear first and foremost as transaction participants and regulatory subjects, with little by way of regulatory background where states traditionally predominate. The ambiguous role of the states would make the Governance Triangle an uneasy fit.

As a school of thought, new governance claims a large cadre of prominent academics, and has had a measure of policy influence. ${ }^{70}$ Yet others have criticized its theories as illdefined. New governance prescriptions, particularly with respect to accountability, have faced scepticism familiar to students of soft law: putting unelected private actors in charge of regulation risks regulatory capture by powerful elites, and may undermine electoral democracy and government capacity. ${ }^{71}$

\footnotetext{
${ }^{68}$ See e.g., Frederick Mayer \& Gary Gereffi, Regulation and Economic Globalization: Prospects and Limits of Private Governance, Business and Politics: Vol. 12: Iss. 3, Article 11 (2010).

${ }^{69}$ Kenneth W. Abbott \& Duncan Snidal, Strengthening International Regulation Through Transnational New Governance: Overcoming the Orchestration Deficit, 42 Vand. J. Transnat'I L. 501 (2009); Kenneth W. Abbott \& Duncan Snidal, The Governance Triangle: Regulatory Standards Institutions and the Shadow of the State in in THE POLTICS OF Global Regulation (Walter Mattli \& Ngaire Woods, Eds., 2009).

${ }^{70}$ Symposium: NeW Governance And the Transformation of LaW 2010 Wis. L. Rev.

${ }^{71}$ Colin Scott, Regulation in the Age of Governance: The Rise of the Post Regulatory State, in JACINT JORDANA \& DAVID LeVi-Faur, eds., The Politics of Regulation: Institutions and Regulatory Reforms for the Age of Governance 145 (2004); John M. Conley \& Cynthia A. Williams, Global Banks as Global Sustainability Regulators?: The Equator Principles, 33 Law \& Policy 542 (2011). But see Ian Ayres \& John Braithwaite, Responsive Regulation: Transcending the Deregulation Debate (1992) on tripartism as a capture-mitigant.
} 
Empirical studies of the effectiveness of new governance are still sparse and inconclusive. ${ }^{72}$ This is not surprising for a field that is relatively new, and (depending on your perspective) either radically heterogeneous or ill-defined. Much of the empirical research agenda has focused on documenting the phenomenon of the new governance in regulation. Qualitative studies in particular tend to focus on the informants' experience of new governance, and are cautious in their efficacy assessments. However, several go further, to consider the success of new governance schemes in achieving their stated goals, or to tease out the factors that contribute to the impact of particular initiatives.

No study finds unqualified success. There is evidence that corporations excel at formal compliance and new governance rhetoric, with limited or inconsistent effect on their behaviour. ${ }^{73}$ However, the same studies find palpable changes in institutional culture and awareness. Another notable finding is that weak nonstate actors (such as poor people) may be at a disadvantage in a purely informal governance regime, and need a hard law backstop to bolster their bargaining position. ${ }^{74}$

Even so, asking whether new governance "works" may be beside the point: successful or not, new governance phenomena are pervasive. ${ }^{75}$ Just as treaties may not be a practical alternative to soft law, old-style regulation is not always a practical alternative to new governance. ${ }^{76}$ For purposes of implementing the Principles, the relevant inquiry would identify more and less successful strategies for achieving compliance, find ways to link soft and hard law, and help establish realistic goals.

So far, theory and experience with new forms of regulation suggests that at a minimum, they help change the way firms talk about responsible behaviour, and the way in which they interact with civil society and government actors. This affects firm culture and

\footnotetext{
${ }^{72}$ For examples in law journals, see John M. Conley \& Cynthia A. Williams, Global Banks as Global Sustainability Regulators?: The Equator Principles, 33 Law \& Policy 542 (2011); Christie Ford \& David Hess, Can Corporate Monitorship Improve Corporate Compliance? 34 J. Corp. L. 680 (2009); Lisa T. Alexander, Stakeholder Participation in New Governance: Lessons from Chicago's Public Housing Reform Experiment, 16 Geo. J. Poverty L. \& Policy 118 (2009); France Houle, Consultation During Rule-Making: A Case Study of the Immigration and Refugee Protection Regulation, 28 Windsor Y.B. Access Just. 395 (2010); Yuval Feldman \& Orly Lobel, The Incentives Matrix: The Comparative Effectiveness of Rewards, Liabilities, Duties, and Protections for Reporting Illegality, 88 Tex. L. Rev. 1151 (2010). In social science journals, see e.g. Jodi Short \& Michael W. Toffel, Making Self-Regulation More Than Merely Symbolic: The Critical Role of the Legal Environment, 55 Admin Sci. Q. 361-396 (2010).

73 John M. Conley \& Cynthia A. Williams, Engage, Embed, and Embellish: Theory Versus Practice in the Corporate Social Responsibility Movement, 31 J. Corp. L. 1 (2005); John M. Conley \& Cynthia A. Williams, Global Banks as Global Sustainability Regulators?: The Equator Principles, 33 Law \& Policy 542 (2011); Christie Ford \& David Hess, Can Corporate Monitorship Improve Corporate Compliance? 34 J. Corp. L. 680 (2009).

${ }^{74}$ Lisa T. Alexander, Stakeholder Participation in New Governance: Lessons from Chicago's Public Housing Reform Experiment, 16 Geo. J. Poverty L. \& Policy 118 (2009).

${ }^{75}$ Compare Kal Raustiala, Transnational Networks: Past and Present, 43 Int'I L. 205 (2009).

${ }^{76}$ For example, states may lack economic or political resources to implement effective top-down regulation.
} 
holds out the potential of changing behaviour. ${ }^{77}$ Empowering civil society participation in the regulatory process through fostering awareness and opening access may help reduce the risk of capture. ${ }^{78}$ The presence of hard law in the background-notably in the form of induced competition and information-forcing surveillance, as alternatives to coercive sanctions ${ }^{79}$ - can help soft law succeed in a new governance framework. This poses a special challenge for international law making, where hard law is scarce. Scholars who have considered the problem recommend more active "orchestration" and capacity-building by international organizations, using tools such as conditionality and technical assistance. ${ }^{80}$ The academic literature on new governance also emphasizes the need for context-specific approaches, and frequent adjustment as the context evolves and more information becomes available.

In Part, I have sought to situate the Principles in the existing legal landscape of sovereign borrowing and lending, and in the context of theories about soft law and new governance. In sum, domestic and international "hard law" play a small role in sovereign debt compared to most other fields. The sovereign debt restructuring regime is dominated by soft law coordination, fragmented and poorly understood by the public. This regime in turn creates the incentives for borrowing and lending, which occur "in the shadow" of restructuring expectations.

Academic writing and experience with soft law and new governance suggest that informal and nonbinding mechanisms such as the Principles can improve regulation and compliance in some circumstances. However, they must be properly designed to minimize the risks of error, capture, and illegitimacy. To get a better sense of the optimal design features before turning to implementation recommendations, Part II briefly considers five new governance-style codes in international finance and development. In conclusion, I review the evolution of anti-corruption law from national legislation to transnational "soft" governance, and later international treaty. These case

\footnotetext{
${ }^{77}$ This reflects Mattli and Woods' view that both supply (access, process) and demand must be present to avoid capture. Particularly where transparency and access to the regulatory process are limited, select NGOs and corporate monitors may be coopted, becoming "legitimators."

78 Ian Ayres \& John Braithwaite, Responsive Regulation: Transcending the Deregulation Debate (1992) (discussing tripartism and "enforced" self-regulation).

${ }^{79}$ Charles Sabel, Dara O'Rourke \& Archon Fung, Ratcheting Labor Standards: Regulation for Continuous Improvement in the Global Workplace, KSG Working Paper No. 00-010; Columbia Law and Economic Working Paper No. 185; Columbia Law School, Pub. Law Research Paper No. 01-21, May 2000, available at http://ssrn.com/abstract=253833 or http://dx.doi.org/10.2139/ssrn.253833; Jodi Short \& Michael W. Toffel, Making Self-Regulation More Than Merely Symbolic: The Critical Role of the Legal Environment, 55 Admin Sci. Q. 361-396 (2010).

${ }^{80}$ Kenneth W. Abbott \& Duncan Snidal, Strengthening International Regulation Through Transnational New Governance: Overcoming the Orchestration Deficit, 42 Vand. J. Transnat'I L. 501 (2009).
} 
studies, where the actors addressed similar or overlapping problems, will help contextualize the prescriptions for Principles implementation.

\section{Part II: Ancestors and Analogues}

The Principles have no direct precedent, and are in many ways more ambitious than the existing codes of best practices in international finance: they seek to cover more instruments and discipline more diverse actors than the initiatives that have come before; they are also more substantively prescriptive than others in the field. However, the past decade has produced a wealth of experience with codes and practices, which together shed light on potentially promising strategies and pitfalls in Principles implementation. This Part offers a brief survey of five new governance initiatives, chosen to reflect different aspects of the Principles. All came about within the past decade, and are notable for their multi-stakeholder approach-especially when compared to the standards and codes of the 1990s, predominantly devised by the official sector to improve regulation in low and middle-income countries. The first two case studies, the Equator Principles and the Extractive Industries Transparency Initiative, seek to enhance social and environmental responsibility and promote accountability in discrete privately financed sectors. In the next two case studies, the Paris Declaration and the Santiago Principles, the authors and subjects of regulation are states or state instrumentalities. The final case study is most closely related to the UNCTAD Principles: the Principles for Stable Capital Flows and Fair Debt Restructuring seek to govern sovereign borrowing and debt restructuring in the capital markets. The later set of principles targets government debtor and private creditor behavior. In conclusion, I discuss an earlier experience with anti-corruption initiatives for an illustration of soft law hardening into international treaty, while maintaining features of new governance.

\section{A. The Equator Principles}

The Equator Principles (EPs) are a framework for managing social and environmental risk from project finance by commercial banks. Adopted in 2003 and substantially revised in 2006, the EPs reflect a combination of diminished official participation in large-scale infrastructure in developing countries, sustained NGO advocacy, and a heightened perception of risk on the part of the banks.

Although they articulate substantive social and environmental sustainability goals, the ten principles are essentially procedural: they commit banks to require their borrowers 
(project sponsors) to adopt responsible practices, focusing on projects in developing countries. Participating banks, or Equator Principles Financial Institutions (EPFIs), pledge to (1) review and categorize projects over \$10 million according to social and environmental impact, and to require their borrowers to (2) conduct impact assessments, (3) use International Finance Corporation (IFC) standards in such assessments, (4) develop plans for managing the associated risks, (5) engage in consultations with, and provide disclosure to, stakeholders, (6) establish a grievance procedure, (7) secure independent review of the project assessment in higher risk projects, (8) covenant to comply with applicable host country laws, IFC standards, disclosure and decommissioning procedures, and (9) secure independent monitoring of risky projects over the life of the loan. (10) In addition, the EPFIs themselves agree to report at least once a year on their EP practices and experience. Like many initiatives of this sort, the EPs contain a disclaimer to the effect that they concern internal procedures of the participants, and do not create rights or binding obligations. ${ }^{81}$ Nevertheless, the mechanism hinges on a mix of organizational practices and a network of enforceable contractual commitments, which the EPFIs pledge to extract from their counterparties.

Membership has grown from ten EPFIs in 2003, to $73^{82}$ at this writing, which accounts for over $70 \%$ of all international project financing in the developing world. In 2010, the EPFIs formed the EP Association, a "soft," unincorporated grouping of all member institutions, which operates under a set of rules promulgated by the membership. Subject-matter working groups are coordinated by a fourteen-member Steering Committee. A two-person EP Secretariat, based in the UK, staffs the Association on a day-to-day basis. The EPs were revised in 2006 to incorporate new, more stringent IFC standards, and are undergoing another round of revision following a strategic review in 2011. Release of the updated EPs has been postponed until mid-2012. ${ }^{83}$

The EPs are an established example of soft law and new governance. They are among the more institutionally developed initiatives of this sort. Several design features of the EPs are worth noting in the context of Principles implementation:

- Financial Institutions as Principal Subjects and Law-Makers. The EPs originated as pre-emptive self-governance among a core group of financial institutions, which

\footnotetext{
${ }^{81}$ The Equator Principles, available at http://www.equator-principles.com/resources/equator principles.pdf (last visited February 12, 2012).

${ }^{82}$ This includes two "Associate Members" (JP Morgan Chase and Wells Fargo), which have adopted the EPs and abides by EP reporting requirements, but are not "active in project finance" according to the EP definition.

83 See PRIZMA, Launch of Equator Principles III Delayed to July 2012 (Jan. 10, 2012) available at http://prizmablog.com/2012/01/10/launch-of-equator-principles-iii-delayed-to-july-2012/.
} 
approached the IFC. EPFIs are both members and principal subjects of regulation.

- Adoption and Membership. The EPs contain bright-line criteria for adoption and membership. Even though the EPs themselves are adopted voluntarily and do not, by their terms, create rights in members or other stakeholders, the clear act of joining, paying membership fees, and signing up to specific standards, serves as a commitment and community-defining device.

- Recruiting. Comprehensive coverage of the project finance industry is an explicit objective of the EPs. Members, together with IFC representatives, actively recruit new EPFIs, paying attention to country and regional representation.

- Constituency Definition and Outreach. The EP consultation and governance process expressly seeks to balance regional, sector, and interest group representation. Project-specific consultation under the EPs should include a broad range of stakeholders.

- Elaboration and Adaptation. The EPs are regularly elaborated and periodically revised, including most recently as part of a high-profile strategic review. Subsidiary and interpretive documents and guides refine and augment the code.

- Harmonized Disclosure and Reporting. The EPs mandate disclosure at multiple levels of both the EPFIs and their borrowers, and promulgate standards for disclosure to promote comparability.

- Decentralized Dispute Resolution. There is no centralized dispute resolution or binding interpretation process for the EPs. Each EPFI commits to require its borrowers to establish project-specific and "culturally appropriate" grievance procedures for the stakeholders.

- Capacity Building. The EPs provide for a transitional period and technical assistance for new members.

- Linkages with "Hard" Law and Institutions. The EPs originated in bank consultations with the IFC. They explicitly adopt IFC standards, as well as some World Bank and OECD nomenclature, and advocate compliance with national legislation where it equals or exceeds IFC standards. The EP Association is continuously engaged with the relevant international organizations.

- Branding. The "Equator Principles" name was designed to signal North-South balance. Because so much of the payoff to EPFIs is reputational, the process has a highly developed branding and public relations strategy, including a current and generally informative website.

As with virtually all new governance initiatives, assessments of the EPs' efficacy are inconclusive. In one sense-membership and industry coverage-the EPs have been a 
resounding success. However, quantitative studies of development outcomes are few, and those that exist supply no definitive answers. Some proponents claim that the EPs have changed the behavior of large firms; however, even optimistic assessments note that smaller firms lack the resources to comply. ${ }^{84}$ Critics stress the absence of a demonstrable shift in environmental and social outcomes on the ground. ${ }^{85}$ In a detailed qualitative study, one team of scholars has noted that participation in the EPs affects firm culture at the EPFIs, and potentially promotes awareness and better practices within these banks beyond their project finance portfolio. ${ }^{86}$ In this sense, EP banks have the capacity to diffuse standards of responsibility both within the project finance industry and elsewhere in the banks' business. Nevertheless, this research also casts doubt on the true sources and viability of the commitment pull: although the EPs are expressly framed as bank risk management, most of the bankers interviewed were ambivalent about the business case for the EPs, and justified participation in terms of responding NGO pressure. Such findings echo stories of pre-emption, self-preservation, and cosmetic compliance in other industries.

\section{B. Extractive Industries Transparency Initiative}

The Extractive Industries Transparency Initiative (EITI) emerged at about the same time as the EPs, in 2003, with strong leadership of the UK authorities and NGOs, such as Publish What You Pay Coalition. EITI promotes transparency and accountability in the extractive industries through public disclosure of "all material oil, gas, and mining payments" by firms to governments, and all material government revenues from oil, gas, and mining companies. The focus of the six EITI Criteria appears to be even more targeted and procedural than that of the EPs: it is all about disclosure. However, the twelve EITI Principles articulate a much broader set of objectives, ranging from sustainable development and responsible stewardship of natural resource wealth, to improving public finance management and accountability. ${ }^{87}$

The structure of EITI is quite different from the EPs:

- Governments as Subjects of Regulation. Although the overall framework is expressly and emphatically "multi-stakeholder," and includes major extractive

\footnotetext{
${ }^{84}$ See Christopher Langdon, The impact of the Equator Principles on mining and metals finance in emerging markets, White \& Case LLP (Mar. 2007).

${ }^{85}$ See Nick Mathiason, Banks Attacked for Failures to Meet Equator Principles on Environment, The Guardian (Jan. 10, 2010).

${ }^{86}$ Project finance accounts for about $5 \%$ of the large institutions' portfolio. Conley \& Williams (2011).

${ }^{87}$ http://eiti.org/files/2011-11-01_2011_EITI_RULES.pdf
} 
firms and civil society participation, the parties principally charged with compliance are countries. EITI Countries are held responsible for the reporting of firm payments in their jurisdiction, and creating structures for such reporting.

- Private Firms as "Supporting Investors." Private firms are invited to participate in the EITI process by signing onto a statement of support, engaging in certain publicity and outreach, and paying an annual fee of US\$1,500; however, "supporting" status does not trigger reporting requirements. According to the EITI factsheet, supporting the initiative helps demonstrate investor compliance with Principles 3 and 5 of the UN Principles for Responsible Investing. ${ }^{88}$

- Other Supporters. Civil society organizations, industry associations, nonmember countries, and international organizations may all become supporters of EITI. For the most part, supporter status involves no or minimal undertakings.

- Graduated Membership Structure. Countries must have at least a two and a half year record of compliance with EITI criteria to qualify for full membership. This structure can support capacity building, but also sanction non-compliance. Regular reviews validate continued membership. Yemen and Madagascar have had their membership suspended.

- Emphasis on Tripartism. EITI explicitly requires tripartite governance of country EITI participation, including governments, extractive firms, and civil society representatives in ongoing consultations. In other words, EITI expressly aspires to occupy the center of the Governance Triangle.

- External Independent Evaluation. A team of independent consultants provided a strategic evaluation of EITI in 2011.

- Formal Corporate Structure, Funding and 10 Linkages. The EITI is organized as a nonprofit association in Norway. Since the mid-2000s, it has had a 20-member Board, a Secretariat, and access to a multi-donor trust fund managed by the World Bank. Most of its funding comes from member governments, supporting firms, and NGOs; however, the Government of Norway provides fully $20 \%$ of the fund. ${ }^{89}$ The Multi-Donor Trust Fund provides technical assistance to implementing countries.

- Global Conferences. The biennial EITI Global Conference is an important component of EITI governance. The Board is appointed at the conferences. During the conference, EITI also constituency meetings with countries, firms, and civil society.

- Further Linkages and Related Initiatives. The IMF has published a Guide to Resource Revenue Transparency. The World Bank has published the Extractive

\footnotetext{
${ }^{88}$ http://eiti.org/files/2009-11-23_How_to_Support_Investors[1].pdf

${ }^{89}$ http://eiti.org/about/funding.
} 
Industry Review. In 2010, U.S. legislation mandated disclosure of extractionrelated payments by firms applying to register securities with the SEC. ${ }^{90}$

As with other case studies, academic empirical studies of EITI are hard to come by. Country membership and supporter lists have grown, and now include major portions of the global extractive industry. Liberia became the first country to expand EITI beyond extractive industries, to include forest management. A strategic evaluation conducted for EITI by independent consultants from Scanteam in 2011 has found that the initiative has had some success in establishing tripartite governance and reporting mechanisms in the member countries. However, according to the report, "[w]hile transparency has improved, accountability does not appear to have changed much." The reviewers attribute the limited societal and global effects on the targeted focus of the initiative, weak institutions in member countries, limited linkages and a lack of a broader vision for how improved reporting would leverage social change. ${ }^{91}$ NGO critics are less charitable. According to Oxfam America, there is a "yawning gap" between the actions and rhetoric of oil companies supporting EITI. ${ }^{92}$ Other argue that EITI shields companies from criticism while they fight disclosure rules on extraction-related payments by the U.S. securities regulators. ${ }^{93}$ NGOs have also criticized national EITI chapters for failing to live up to the initiative's transparency standards. ${ }^{94}$

An academic synthesis of implementation assessments acknowledges EITI's shortcomings, while pointing out that some of the development impacts of transparency would be hard to measure. ${ }^{95}$ On the other hand, the authors note design failures that reduce constituent ownership and with it, development impact. For example, countries' EITI disclosure appears to be geared disproportionately to external audiences. Domestic constituents have scant economic, technical, and political capacity to process and use the information generated from EITI.

It appears that the focus on government-led implementation at a minimum makes it difficult to assess the effect of EITI on the behavior of private actors. The international prominence of the initiative has contributed to its external focus, which in turn potentially reduces domestic ownership. However, to the extent the primary concern of the initiative is public finance reform and accountability, rather than reform of a

\footnotetext{
${ }^{90}$ The Dodd-Frank Act, Sec. 1504.

${ }^{91} \mathrm{http}: / /$ eiti.org/files/2011-EITI-evaluation-report.pdf.

${ }^{92} \mathrm{http}: / /$ politicsofpoverty.oxfamamerica.org/index.php/2012/02/09/the-transparent-hypocrisy-of-big-oil/.

${ }^{93}$ http://www.trust.org/trustlaw/blogs/anti-corruption-views/transparency-is-for-life-not-just-for-pr; http://www.chron.com/business/article/Oil-industry-battles-SEC-rules-on-disclosure-3334841.php.

${ }_{94}^{94}$ http://www.vanguardngr.com/2012/01/ngo-tasks-neiti-on-transparency-accountability/.

95 Alexandra Gillies \& Antoine Heuty, Does Transparency Work? The Challenges of Measurement and Effectiveness in Resource-Rich Countries, 6 Yale J. Int'l Aff. 25 (2011).
} 
broader set of extractive industry and development practices, it may be unfair to hold EITI responsible for the limited or uncertain effect it has had on the industry.

\section{The Paris Declaration on Aid Effectiveness}

Unlike the initiatives in the preceding case studies, which sought to affect to varying measures the behavior of both public and private actors, the 2005 Paris Declaration is a purely intergovernmental undertaking, albeit one that invites civil society participation. The Declaration comprises five fundamental principles of aid effectiveness: ownership by recipient countries, alignment of the donors and use of local systems, harmonization of procedures and information-sharing among donors, a focus on measurable development results, and mutual accountability of donors and recipients for such results. Flowing from these principles, the Declaration provides for over fifty commitments, monitored by twelve indicators. The Accra High Level Forum adopted an Agenda for Action in 2008 to accelerate the implementation of the Declaration. This timing proved challenging with the onset of the global financial crisis, which strained aid resources.

The Paris Declaration's use of tiered, open-ended principles elaborated in ongoing consultation and evaluation procedures, generally administered under the auspices of the OECD's Development Co-Operation Directorate, recalls familiar soft law and new governance forms. Invocation of mutual accountability and collaborative program development is also consistent with the paradigm. However, the initiative essentially uses existing inter-governmental and institutional channels to promote improved aid effectiveness.

OECD-led assessments of the Declaration's impact show progress in establishing and reforming recipient country institutions for policy development and aid administration. ${ }^{96}$ There is also some evidence of increased aid volumes. However, an independent audit completed in 2011 suggests that changes on the donor end have been very limited. ${ }^{97}$ Whether this is a structural deficiency or a function of the crisis is difficult to assess at this time.

It is also too early to draw lessons from the Paris Declaration for implementation of the Principles. Although the Declaration has articulated ambitious goals, and has proceeded to elaborate them in successive meetings, it did not emphasize institutional innovation in the way the more hybrid public-private initiatives have done.

\footnotetext{
${ }^{96}$ OECD, Aid Effectiveness 2005-2010: Progress in Implementing the Paris Declaration (2011).

${ }^{97}$ The Evaluation of the Paris Declaration, Phase 2, Final Report (2011).
} 


\section{The Santiago Principles ${ }^{98}$}

The Generally Accepted Principles and Practices for Sovereign Wealth Funds, unveiled in Santiago, Chile, in August 2008 (hence Santiago Principles), are essentially a public sector initiative like the Paris Declaration. However, the Santiago Principles bring together very different kinds of government actors-international investment vehicles of surplus countries-and for a very different purpose than the traditional aid enterprise.

State-owned investment vehicles or Sovereign Wealth Funds (SWFs) proliferated in the mid-2000s, but also faced an increasingly hostile investment environment in Europe and the United States. At the outset, many SWFs saw one another as competitors and were not inclined to collaborate. The idea of a best practices code emerged in G-20 discussions in 2007, and received a boost from the development of academic, commercial, and think tank assessments of the SWFs. ${ }^{99}$ The goal was to improve transparency and accountability of the SWFs, and thereby to make them seem less threatening to the host countries. Because SWF sponsors had no need for official funding, conditionality was not available as a lever to change individual SWF behavior. Any resulting code would have to be "soft," or nonbinding. Members of the International Working Group (IWG) refrained from describing their work product as "best" practices-but rather as generally accepted practices suitable for countries across the national income spectrum. ${ }^{100}$ The IMF was invited to facilitate the development of the principles and serve as the initial IWG secretariat based on its macroeconomic and technical expertise, without explicit program or surveillance links. Participants in the development of the Santiago Principles over the first half of 2008 report that a community of interests gradually emerged among disparate SWFs.

The two dozen Santiago Principles address the structure and objectives of SWFs ("legal, institutional and macroeconomic" factors), their governance practices (especially decision autonomy from the home government) and their investment and risk management policies, focusing on financial stability. The document is suffused with accountability rhetoric, which is cited in support of all but a few of the two dozen principles. At the same time, the Santiago Principles take a particular view of accountability that is distinct from earlier public statements by SWF and host governments: SWFs promise to act and be accountable as market actors, not political

\footnotetext{
${ }^{98}$ Portions of this section were previously published in Anna Gelpern, Sovereignty, Accountability, and the Wealth Fund Governance Conundrum, 1 As. J. Int'I L. (2011).

${ }^{99}$ See e.g., the Truman Scoreboard at www.piie.org.

${ }^{100}$ Generally Accepted Principles \& Practices (GAPP), GAPP 5.
} 
entities. They go the farthest in answering to their narrow stakeholders under the terms of their constitutive arrangements, ${ }^{101}$ abiding by the laws their hosts made applicable to similarly situated investors, ${ }^{102}$ and participating in the global financial markets in the manner of profit-driven private investors. ${ }^{103}$ The most significant disclosure is made to the owner, not the domestic public, effectively relying on general government channels to inform the populace and the world at large. ${ }^{104}$ Domestic political sensitivities trumped transparency in important instances: for example, SWFs are not required to disclose the size of their asset holdings. ${ }^{105}$

Because the objective of SWFs was to demonstrate their commercial essence despite their public ownership, the Santiago Principles seek to distance the signatories from the social responsibility agenda: SWFs are in the business of maximizing "risk-adjusted returns" and operate solely "based on economic and financial grounds". Any social, ethical or religious motive is a deviation from the group norm (albeit one in which some important members like Kuwait and Norway engage), which must be specifically disclosed. Disclosure obligations elsewhere in the document are justified in terms of dispelling "concern about potential noneconomic or nonfinancial objectives." ${ }^{106}$ The funds' contribution to global financial stability comes not of a sense of public duty, but rather of their capacity-by virtue of their economic objective and structure- "to take a long-term view in their investments and ride out business cycles." ${ }^{107}$

When IWG announced agreement on the Santiago Principles, its members were at pains to disassociate them from the IMF surveillance process: they insisted that everything about the principles was voluntary. Perhaps as a matter of preemption, the Santiago Principles incorporated a periodic internal review mechanism. ${ }^{108}$ In theory, nothing prevents the IMF from considering GAPP criteria in its assessment of home and host policies implicating SWFs, just as nothing prevents a host government from using GAPP as part of its investment screen. ${ }^{109}$ But doing so may undermine the Principles'

\footnotetext{
101 GAPP 6-10.

102 GAPP 15. A press report went so far as to designate compliance with host country disclosure laws as "the most significant of the 24 guidelines" in the Santiago Principles. Cash in Hand, The Economist, 19 June 2010, at 68. This characterization is somewhat puzzling since, unlike some of the other GAPP items, GAPP 15's non-binding exhortation to abide by already-binding legal rules yields no new content and uncertain additional commitment.

103 GAPP 2, 17, 19.

104 GAPP 5.

105 See e.g., Edwin M. Truman, Blueprint, at 27; Edwin M. Truman, Sovereign Wealth Funds: Threat or Salvation? at 112 (2010).

${ }^{106}$ GAPP 21; see also, e.g., GAPP 6, GAPP 16 Explanations and Commentary.

107 Santiago Principles: Objective and Purpose, GAPP at 3.

108 Press Conference Call Transcript, supra note 29.

${ }^{109}$ Some members of the U.S. Congress have suggested using CFIUS review to encourage SWF compliance with best practices, albeit omitting specific reference to GAPP. See Press Release, House Financial Services Committee, Frank, Maloney, Gutierrez Call on Treasury to Address Sovereign Wealth Funds in FINSA Regulations, March 13, 2008,
} 
legitimacy in the home countries, and scuttle cooperation between new and old powers and institutions.

Shortly after releasing the principles themselves, the IWG secretariat released a SWF survey, answering calls for transparency while seizing initiative and asserting control in a field where authoritative information was scarce and analysis was dominated by private investment banks and consultancies. ${ }^{110}$ Six months after presenting the Principles to the IMFC, the group released the Kuwait Declaration establishing a standing forum of SWFs. IWG's successor, the International Forum of Sovereign Wealth Funds (IFSWF) is "a voluntary group of SWFs" whose membership is open to funds that meet the GAPP definition of SWF and, significantly, "endorse" the Principles. It is a soft institutional counterpart to the emphatically soft law of the Santiago Principles. ${ }^{111}$ The IFSWF has met periodically in member capitals, has issued statements advocating open investment, and has brokered a code of "good practices" on investment risk management, conducting member surveys as part of the process. ${ }^{112}$

The following features of the Santiago Principles process merit attention for purposes of Principles Implementation:

- Membership Criteria. In the case of SWFs more than any other, a common definition of regulatory subjects was missing-SWFs were just too diverse and contested as a phenomenon. Defining the category, and requiring members to formally endorse the Santiago Principles as a condition of joining, established a community, a code of behavior, and a sanction ${ }^{113}$ in one step. This is similar to the concepts of EPFIs and EITI Member Countries.

- Common Defense Motive. Diverse SWFs were ultimately prodded into cooperation by common fears about protectionist laws in host countries. The code is unlikely to have emerged without this background risk.

- Elaboration, Reporting, and Institutionalization. The initial code of behavior was quickly supplemented by information release and more inward-looking best practice efforts for the benefit of SWF members.

available at http://financialservices.house.gov/press110/press0313082.shtml; TRUMAN, THREAT OR SALVATION, supra note 19 , at 100 .

${ }^{110}$ Sovereign Wealth Funds: Current Institutional and Operational Practices (Sep. 15, 2008), available at http://iwgswf.org/pubs/swfsurvey.pdf. SETSER REPORT, supra note 9, at 40 (noting a decline in transparency).

${ }^{111}$ International Working Group of Sovereign Wealth Funds, "Kuwait Declaration": Establishment of the International Forum of Sovereign Wealth Funds, Apr. 6, 2009, at www.iwg-wf.org/mis/kuwaitdec.htm.

112 Int'l Forum of Sovereign Wealth Funds, Sovereign Wealth Funds Issue "Baku Statement" Reaffirming the Need for Maintaining Open Investment Environment, 9 Oct. 2009, at http://www.ifswf.org/pr/pr2.htm.

${ }^{113}$ For example, limitations on membership. 
- Limited Emphasis on Disclosure and Civil Society Collaboration. In one important respect, the Santiago Principles are unlike other new governance initiatives. Although transparency and SWF-host collaboration are important objectives, the funds' commitment to these goals is carefully circumscribed owing in large part to domestic political constraints. Civil society participation and social consciousness are de-emphasized.

- Involving International Organizations as Facilitators. The IMF's role in the Santiago Principles process may be akin to UNCTAD's role in the preparation of the Principles.

- Role of Non-Governmental Monitors. The presence and continued reporting by think tanks and industry observers contributed to the content and implementation of the Santiago Principles. There is ample evidence of competing outside metrics influencing the content of the Santiago Principles, of SWFs tracking and seeking to improve their "scores" (sometimes by lobbying the scorekeepers), and trying to preempt outside monitoring by supplying their own information.

The Santiago Principles implementation record is limited-they are just over three years old. However, judging by outside assessments, many SWFs have improved their disclosure to varying degrees in the process of negotiation and early implementations. Because SWFs' objectives are limited and commercial, they also face a lower assessment bar than the development-focused initiatives discussed in the three preceding case studies.

\section{E. Principles for Stable Capital Flows and Fair Debt Restructuring}

The Principles for Stable Capital Flows and Fair Debt Restructuring in the Emerging Markets (Emerging Markets Principles) were developed under the auspices of the Institute for International Finance in 2004, partly responding the controversy surrounding Argentina's debt crisis in 2001 and the ensuing debate about sovereign bankruptcy and sovereign debt contract reform. Like the EPs and the Santiago Principles, the Emerging Market Principles were adopted partly as "market selfdefense": large issuers and creditors felt threatened by the prospect of a statutory sovereign bankruptcy regime, but were amenable to a code of conduct, especially if adopting it would help defeat the bankruptcy proposal. ${ }^{114}$

\footnotetext{
114 Eric Helleiner, Filling a Hole in Global Financial Governance? The Politics of Regulating Sovereign Debt Restructuring in The Politics of Global Regulation (Walter Mattli \& Ngaire Woods, Eds., 2009).
} 
The Emerging Markets Principles exhibit the familiar characteristics of soft law and new governance: they are nonbinding, open-ended and specified over time, and designed to secure parallel undertakings from borrowers and creditors. They only apply to a subset of countries and instruments, and are thus considerably narrower in scope and have fewer constituents than the Principles for Responsible Lending and Borrowing.

The Emerging Markets Principles have four basic prongs: transparency and timely flow of information, debtor-creditor cooperation to avoid restructuring, good-faith actions, and fair treatment. At the outset, they were adopted by major financial institutions and supported by emerging markets borrowers. Elements of the official sector, including the G-20 and the International Monetary and Financial Committee of the IMF, have "noted" and "welcomed" the Emerging Markets Principles, but have stopped short of robust endorsement.

The Principles Consultative Group (PCG), comprising 31 representatives of sovereign borrowers and leading financial institutions, meets periodically as the governance organ of the Emerging Markets Principles. The Group of Trustees of the Principles, comprising "elder statesmen" in sovereign finance consider the overall development of the Emerging Markets Principles in the context of the international financial system, and may recommend modifications. The Institute for International Finance (IIF) (an industry group representing large financial institutions) was the leading force behind the Emerging Market Principles and serves as the secretariat. While other financial industry groups have indicated co-sponsorship and support for the Emerging Market Principles, none are as vocal in proclaiming their relevance. In the run-up to publication and since, there have been reports of dissent within financial industry ranks with respect to the content and application of the principles. ${ }^{115}$

Like the other initiatives considered here, the Emerging Markets Principles come with periodic reporting and self-assessment, elaboration and refinement by the PCG, staffed by the IIF. Unlike some of the others, the Emerging Markets Principles have a discrete view of their constituents: major financial institutions and governments in major emerging market countries. Like the Santiago Principles, the Emerging Markets Principles do not aspire to civil society participation, or a broader social reform agenda. Nor have there been large-scale independent audits of the sort more developmentfocused initiatives, such as EITI, have undergone.

Critics of the initiative point to the prominent role of IIF, infighting and defections among private creditor constituents, and the apparently provisional engagement by

${ }^{115}$ Id. 
both the developing countries and the official sector, as evidence that the Emerging Markets Principles are unlikely to succeed on their own relatively circumscribed terms. ${ }^{116}$ At this writing, the Emerging Markets Principles are being tested in Greece, where the IIF has taken the lead in negotiating on behalf of private creditors, and has invoked the Emerging Markets Principles.

The Emerging Markets Principles initiative can claim the largest measure of success in fostering professionalized ex-ante debt management, such as establishment of debt management offices and improving disclosure practices among emerging markets countries. It is difficult to tell to what extent these changes might have happened absent the Emerging Markets Principles.

This Part has surveyed five case studies of soft law and new governance initiatives in development finance. The key insight is that while all five are informal and nonbinding, they take rather different institutional forms, which may in turn help predict or explain their performance. To be fair, none of the five can boast a deep record of implementation, especially as measured by development outcomes on the ground.

The Equator Principles appear to have a robust infrastructure for engaging direct participants in project finance, and the tightest link between the professed goals and the methods used to achieve them. The EP initiative has a discrete set of objectives, is controlled by the primary subjects of regulation (EPFIs) and benefits from private contract enforcement and linkages to the IFC, which supplies the content of the standards. On the other hand, placing financial institutions at the center of the initiative and relying on contractual mechanisms for stakeholder access and public awareness potentially raises the risk of capture. IFC's orchestration role becomes more important in this context. ${ }^{117}$

The EITI has a more formal and elaborate structure than the EPs, and a more formal connection with the official sector. However, its emphasis on government accountability to govern public and private actors, the indirect commitment of the private extractive

\footnotetext{
${ }^{116}$ Barry Herman, Why the Code of Conduct Falls Short, in Barry HeRman, Jose ANTONIO OCAMPo \& Shari SPIEGEL, EDS., Overcoming Developing Country Debt Crises (2010).

${ }^{117}$ Walter Mattli \& Ngaire Woods, In Whose Benefit? Explaining Regulatory Change in Global Politics, in THE PoLITICS OF Global Regulation (Walter Mattli \& Ngaire Woods, Eds., 2009) (theorizing risk of capture); Kenneth W. Abbott \& Duncan Snidal, Strengthening International Regulation Through Transnational New Governance: Overcoming the Orchestration Deficit, 42 Vand. J. Transnat'I L. 501 (2009) (proposing an orchestration role for international organizations).
} 
industry, as well as the gap between the immediate objective of disclosure and the larger goals of development, creates risks for implementation. On the other hand, independent and public audits and information dissemination practices create incentives for public monitoring, even in the absence of direct obligations on nongovernment stakeholders.

The Paris Declaration is the case study closest to the "old governance" model: it has articulated ambitious goals on aid effectiveness, but has largely eschewed radical institutional innovation in pursuing them. Even so, it has helped secure important improvements in recipient aid management despite relatively weak performance on the part of the donors.

Like the EPs, the Santiago Principles benefit from a delimited constituency, narrowly set goals, and the perception of business risk. The Santiago Principles do not aspire to change the world, but to make it safe for SWF investment. The most interesting element of this initiative for Principles implementation is the role of outside indices and scoreboards, which became an important foil and driver of the Santiago Principles.

The Emerging Markets Principles similarly do not set ambitious development policy goals. They may have played a role in improving ex ante debt management and monitoring on the part of emerging market countries; however, their effect on debt restructuring practices is uncertain. Their close association with a subset of creditors have exposed them to criticism for limited legitimacy.

In conclusion, it is worth considering a much older initiative, which culminated in the 2003 UN Convention on Corruption. Beginning with the enactment of the Foreign Corrupt Practices Act in the United States in 1977, U.S. officials tried to persuade counterparts to adopt similar measures, so as not to put U.S. firms at a disadvantage. However, such efforts largely failed. The campaign got a new life with the formation of Transparency International (TI) in 1993, based in Germany, which began with promoting transparency pacts between governments and bidders for public contracts, and expanded to monitoring and rating countries for public corruption indicators. U.S. negotiators had given up on securing hard law commitments on bribery; however, they enthusiastically supported TI's soft law campaign. The civil society campaign led to a series of soft law instruments (guidelines and recommendations) promulgated by the OECD, a formal international organization, followed by classic hard law - the 1997 OECD Anti-Bribery Convention. Scholars credit the strategic, purposeful collaboration and 
iterative process between state and civil society actors with the success of the effort in changing domestic legislation and norms of behavior in many jurisdictions. ${ }^{118}$

Echoes of this "hardening" trajectory may be found in some of the case studies in this part, including the incorporation of EITI concerns in the Dodd-Frank Act and national legislation in Liberia and Nigeria. However, one must be cautions in implying a necessary and unidirectional relationship between soft and hard law from this case: while some scholars have emphasized complementarity between soft and hard initiatives, others have shown ways in which states and market participants can play soft law and hard law against each other, weakening both in the process. ${ }^{119}$ With these lessons in mind, the next Part contains recommendations for Principles implementation.

\section{Part III: An "All of the Above" Implementation Strategy}

The central premise of this paper has been that the goal of implementation goes beyond formal adoption or widespread endorsement. Implementation of the Principles should be measured by compliance: a drop in unsustainable, unauthorized, and exploitative sovereign debt. Compliance here may take years, sometimes decades, to ascertain. This fact should not detract from the overarching goal. It does raise distinct implementation challenges and tempers expectations of assessment. None of the initiatives discussed in the case studies in Part II can claim to have developed a robust record of compliance in the course of the past decade. ${ }^{120}$

The implementation recommendations that follow draw on the theories of soft law and new governance sketched out in Part I, and on the case studies in Part II. They fall into three categories: endorsement and membership, monitoring and information flow, and institutional linkages. More specifically, the implementation strategy should (i) maintain the nonbinding character of the Principles; (ii) secure clear endorsement from diverse constituents, with diversity measured both geographically, and by sector (states, financial firms, civil society), (ii) continue to elaborate and adapt the Principles to build support; (iv) promote regular monitoring and publicly accessible reporting, using both internal and external mechanisms; (v) forge institutional links with multiple stakeholders

\footnotetext{
${ }^{118}$ Roberta S. Karmel \& Claire R. Kelly, The Hardening of Soft Law in Securities Regulation, 34 Brook.J.Int'IL., 883, 916924 (2009).

${ }^{119}$ Gregory C. Shaffer \& Mark A. Pollack, Hard vs. Soft Law: Alternatives, Complements, and Antagonists in International Governance, 94 Minnesota L. Rev. 712 (2010).

${ }^{120}$ This is not unusual for new governance initiatives. Most are in the early stages of development. For a theoretical explanation, see Bernstein \& Cashore, supra (2007).
} 
and connections to other best practices regimes; and (iv) create a governance body to maintain oversight, review and adapt the Principles, reinforce ties with stakeholders, and potentially administer membership sanctions. I elaborate below.

First, it makes little sense to turn the Principles into a treaty instrument. Especially to the extent they reflect elements of existing law, their best promise lies in their capacity to reach out to diverse audiences, expand the consensus, and adapt to fast-changing circumstances. This feature would be lost to a multi-year process of treaty negotiation, with membership and compliance highly uncertain in the end. Moreover, even where a treaty is in place, remedies for breach may be inaccessible, uncertain or ineffective. This stands in contrast to the general viability of retaliation in trade. Recent literature suggests that soft law has had success in the realm of international financial regulation when it engages new governance techniques; there is untapped potential for both soft law and new governance in sovereign debt.

Second, formal adoption or endorsement of the Principles by governments, G-groups, international financial institutions, civil society and private creditor groups, contract counterparties, and others, is important, but not sufficient. It would of course be useful to have all the stakeholders formally adopt the Principles. Adoption creates a community of interest, channels for information exchange and moral suasion, and ultimately reputational sanctions for not complying with group norms. However, adoption does not correlate perfectly with compliance, and may even mask noncompliance. Selective adoption and implementation of the Principles may be a way to jump-start endorsements; however, it is also fraught with risks of dilution and fragmentation. In particular, it is important to get broad-based buy-in on what constitutes the substantive core of the Principles, which should be protected from variation to the extent possible, even at a cost to formal participation. One possible way to reconcile the need for endorsement now and the strength of commitment down the line is to "tier" elements of the Principles, much like some of the initiatives in Part II: a general and rarely-changed core could be adopted up front, with more specific implications to be further developed by the participants.

Third, the Principles would benefit from substantive and technical elaboration over time. This process can be used to broaden acceptance of the Principles and keep them relevant. For example, if a group of experts from different jurisdictions prepared a report on how sovereign debt contracts or debt management practices might better reflect the goals of the Principles, this would create an implementation vehicle, demonstrate ongoing vitality of the Principles project, and secure ownership in an 
important constituency. Export credit and development agencies, and national debt management offices, are key constituents that could contribute to elaboration, fostering ownership. Other practical reports could address subjects such as interpreting sovereign fiduciary duty across jurisdictions, due diligence and post-disbursement monitoring, domestic legislative implications, the role of the judiciary in implementing the Principles, a "best practices bank," and even debt data collection. Preserving the open and contested character of the Principles is important to continue generating new implementation ideas, and new opportunities for broad-based buy in. The process of elaboration should be open, with reports publicly available and inviting public comment.

Ultimately, the elaboration process may consider whether the Principles should harden, and if so, in what form. Elaboration may take place in multiple stakeholder settings; it may also be centralized in a multi-stakeholder governance forum. Where it is decentralized, coordination is key.

Fourth, monitoring is an essential component of Principles implementation. Apart from promoting accountability, monitoring and reporting may help create positive feedback loops: better due diligence, better risk-management systems, and more generally, a "race to the top" among borrowers, lenders, and monitors. For monitoring to be effective, it must be user-friendly and relevant both to external and internal constituents. It would help to develop specific compliance benchmarks. Three forms of monitoring could be useful; they are not mutually exclusive. Public monitoring and reporting by civil society groups specifically referencing the Principles and any relevant elaboration would promote public accountability and diffusion of the Principles. Facilitating and encouraging such monitoring would put pressure on governments to disclose more, especially with respect to direct and contingent liabilities, and the terms of their debt contracts. At least one dedicated independent monitor with periodic (at least annual) reporting duties to the consultative group, UNCTAD, and/or another organ, would promote better governance for the Principles.

The role of competition in monitoring should be actively considered. Multiple private sector, NGO, and public monitors, at least at the outset, can contribute to improved assessment standards, create broader demand for regulation and information. It is not necessary to decide at the outset on a single rating or compliance certification process. Single compliance metrics would be particularly difficult to articulate in sovereign finance, as distinct from the more traditional context of supply-chain certification. A multi-layered assessment, akin to the SWF scoreboard, would be more appropriate.

Fifth, institutional and operational linkages can help promote durable compliance. For example, incorporating the Principles into the monitoring agenda of existing groups and 
institutions, cross-referencing and linking to other best practices in public and private instruments, would help support wider acceptance the Principles. Embedding the Principles among the standards monitored by international organizations such as the IMF, the FSB, sector and regional groupings, and bilateral creditors, would leverage existing institutional competence to support implementation. In forging such linkages, it is important to engage all relevant stakeholders and create meaningful expectations for their respective roles.

Sixth, a dedicated institutional framework for the Principles, soft or hard, would help coordinate the monitoring and elaboration functions discussed earlier, entrench constituencies for implementation, and embed the Principles in the fabric of sovereign lending and borrowing practice. Institutionalizing broad-based consultations, even after the Principles are substantially fleshed out, should enhance buy-in and ultimately help boost compliance. It bears emphasis that all of the initiatives discussed in Part II came to establish a governance body, some more formal than others, within a few years of their launch. At the outset, a rotating advisory group including representatives of sovereign borrowers, official and private creditors, and civil society, would support the continuing legitimacy and relevance of the Principles. Such a group could oversee the elaboration, adaptation, and refinement. It may make sense to consider two distinct advisory groups: one for lenders, the other for borrowers. Splitting the groups might better channel expertise; on the other hand, it would detract from the valuable holistic character of the Principles, and would require an additional coordination framework. Other institutional forms to consider include a secretariat and a periodic general meeting. These would be in addition to the advisory body. If the Principles enjoy any measure of success, questions of interpretation, standards, membership sanctions, and eventual "hardening" may come up. It would be useful to consider up front a framework for handling such questions.

\section{Conclusion}

This paper has discussed strategies for implementation of the Principles, along with theoretical and pragmatic grounds for the proposed implementation path. These are anchored in the particular qualities of the Principles. The Principles are distinctly ambitious for trying to govern both debtor and creditor practices, including public and private creditors, covering a broad range of instruments, and actively involving civil society stakeholders. This is ultimately a key source of strength for the principles: they 
would likely be seen as even-handed, and therefore more legitimate. The true constituency of the Principles is the global economic system. Properly implemented, they should promote stability and equity within it.

The Principles are also a product of broad-based consultations with diverse government, private sector, multilaterals, and civil society groups. Formal and informal outreach adds to the input legitimacy of the Principles, especially as the content is elaborated and made more specific. The diversity of constituents for the Principles presents an additional process opportunity. The Principles may be "tested" in discrete fields, where they could demonstrate their utility and win broader adherence based on experience. The presence of multiple constituencies presents opportunities for targeted outreach, where proponents may emphasize the Principles' utility to such constituencies, and ultimately, the shared interest in compliance.

The Principles are a mix of well-established principles of national and international law, and an effort at systematization and progressive development of international law governing sovereign lending and borrowing. The Principles do not claim to make new law, but rather to harness and elaborate existing best practices and general principles. Done right, the process of adaptation can create buy-in at the national level at moderate political cost.

By charting both ex-ante and ex-post debt management practices, the Principles frame a comprehensive debt management regime that enhances financial stability. By focusing on due diligence, transparency, and authority, the Principles contribute to crisis prevention. The emphasis on disclosure should facilitate constructive operation of market mechanisms at all stages of the process. Finally, by clarifying the locus and standards of responsibility, the Principles contribute to sound management of debt distress.

All that said, a strategy emphasizing soft law and new governance is by definition uncertain: success is a function of active and purposeful engagement by the participants, some of whom may have limited incentives cooperate beyond cosmetic compliance. Political buy-in, technical and financial resources are hard to come by, and constant revision is burdensome. Nevertheless, none of the "hard" alternatives by itself can ensure implementation. A parallel-track process with thought-out linkages among the tracks stands the best chance of changing borrowing and lending behavior-along with outcomes for development and financial stability. 